\title{
Cortico-cortical connectivity is normalised by levodopa in tremor-dominant Parkinson's disease
}

\author{
Rurak, B.K. ${ }^{1,2}$, Rodrigues, J.P. ${ }^{4}$, Power, B.D. ${ }^{4,5}$, Drummond, P.D. ${ }^{1,2}$, Vallence, A.M. ${ }^{1,2,3}$
}

\begin{abstract}
Background: Resting tremor, which involves involuntary and rhythmic movements of one or more body parts, is the most common presenting motor symptom in Parkinson's disease.

As Parkinson's disease tremor is not associated with the severity of dopaminergic cell loss in the basal ganglia, other brain regions might play a role in its pathophysiology. The supplementary motor area is one of the main targets of the basal ganglia-thalamo-cortical circuit. In turn, the supplementary motor area has direct connections with the primary motor cortex, which is important for the execution of voluntary movement.
\end{abstract}

Objective: The aim of this study was to examine whether supplementary motor areaprimary motor cortex connectivity and dopaminergic neurotransmission are implicated in Parkinson's disease resting tremor.

Methods: Dual-site transcranial magnetic stimulation was used to measure supplementary motor area-primary motor cortex connectivity ON and OFF levodopa medication, and resting tremor was measured using electromyography and accelerometry.

Results: Stimulating the supplementary motor area had an inhibitory influence on primary motor cortex excitability OFF levodopa, which was normalised ON levodopa. The normalisation of supplementary motor area-primary motor cortex connectivity in the ON state might be mediated by an increase in dopamine levels in the basal ganglia, which reduces NOTE: This preprint reports new research that has not been certified by peer review and should not be used to guide glinical practice. nett inhibition of the motor thalamic nuclei and increases excitation of the cerebral cortex. 
medRxiv preprint doi: https://doi.org/10.1101/2022.02.22.22270921; this version posted February 24, 2022. The copyright holder for this preprint (which was not certified by peer review) is the author/funder, who has granted medRxiv a license to display the preprint in It is made available under a CC-BY-ND 4.0 International license .

SMA-M1 connectivity in Parkinson's disease

Supplementary motor area—primary motor cortex connectivity ON medication was inhibitory rather than facilitatory in patients with the strongest resting tremor, suggesting that supplementary motor area-primary motor cortex connectivity might play an important role in resting tremor.

Discussion: The current findings contribute to our understanding of the neural networks involved in Parkinson's disease and provide a neurophysiological basis for the development of interventions to reduce Parkinson's disease resting tremor severity.

\section{Author affiliations:}

1. Discipline of Psychology, College of Science, Health, Engineering and Education, Western Australia, Australia

2. Centre for Healthy Ageing, Health Futures Institute, Murdoch University, Western Australia, Australia

3. Centre for Molecular Medicine and Innovative Therapeutics, Western Australia, Australia

4. Hollywood Private Hospital, Western Australia, Australia

5. School of Medicine Fremantle, University of Notre Dame, Western Australia, Australia

Correspondence to: Brittany K. Rurak

Address: Murdoch University, 90 South Street, Murdoch WA 6150

Email address: brittany.rurak@murdoch.edu.au

\section{Glossary}


medRxiv preprint doi: https://doi.org/10.1101/2022.02.22.22270921; this version posted February 24, 2022. The copyright holder for this preprint (which was not certified by peer review) is the author/funder, who has granted medRxiv a license to display the preprint in It is made available under a CC-BY-ND 4.0 International license .

SMA-M1 connectivity in Parkinson's disease

$\mathbf{A M T}=$ active motor threshold $; \mathbf{E C R}=$ extensor carpi radialis $; \mathbf{F C R}=$ flexor carpi radialis;

FDI = first dorsal interosseous; ISI = inter-stimulus interval; MSO = maximum stimulator output; $\mathbf{M E P}=$ motor evoked potential; $\mathbf{M 1}=$ primary motor cortex $; \mathbf{S} \mathbf{I}_{1 \mathbf{m V}}=$ stimulator intensity to elicit peak-to-peak MEPs of $\sim 1 \mathrm{mV}$; SMA = supplementary motor area; $\mathbf{T M S}=$ transcranial magnetic stimulation. 
medRxiv preprint doi: https://doi.org/10.1101/2022.02.22.22270921; this version posted February 24, 2022. The copyright holder for this preprint (which was not certified by peer review) is the author/funder, who has granted medRxiv a license to display the preprint in

SMA-M1 connectivity in Parkinson's disease

\section{Introduction}

Parkinson's disease (PD) is a heterogeneous neurodegenerative disorder characterised by progressive motor and non-motor symptoms ${ }^{1,2}$. Tremor is the most common presenting motor symptom, involving involuntary and rhythmic movements of one or more body parts, which often develops early in the disease ${ }^{34}$. The pathological hallmark of PD is a progressive degeneration of dopaminergic neurons in the basal ganglia (specifically the substantia nigra), impacting the nigrostriatal pathway, resulting in altered function both in subcortical and cortical areas of the brain important for motor control ${ }^{5,6}$. Dopamine transporter imaging studies show associations between striatal dopamine binding and bradykinesia, but not with PD tremor ${ }^{7,8}$. Furthermore, the response of tremor to dopaminergic medication varies greatly within and between people with PD, with some individuals showing dopamine-resistant tremor ${ }^{9,10}$. Together, these results suggest that dopamine depletion in the basal ganglia cannot fully explain PD tremor; instead, it is hypothesised that functional changes in cortical regions targeted by the basal ganglia might underpin PD tremor.

The supplementary motor area (SMA) is one of the main targets of the basal ganglia-thalamocortical circuit: SMA receives input from the globus pallidus directly and indirectly via the motor thalamic nuclei ${ }^{11-15}$. The main efferent pathway from SMA is to the primary motor cortex (M1) ${ }^{16,17}$. Evidence from functional magnetic resonance imaging (fMRI) in people with PD shows increased blood-oxygen-level dependent (BOLD) activity in SMA and M1 ON compared to OFF levodopa medication during simple motor tasks, such as moving a joystick $^{18,19}$, suggesting that dopamine modulates both SMA and M1 activity in PD. fMRI is useful for showing brain regions that are simultaneously active during a task, but it is unclear 
medRxiv preprint doi: https://doi.org/10.1101/2022.02.22.22270921; this version posted February 24, 2022. The copyright holder for this preprint (which was not certified by peer review) is the author/funder, who has granted medRxiv a license to display the preprint in

SMA-M1 connectivity in Parkinson's disease

whether changes in the BOLD signals are due to excitation of facilitatory or inhibitory circuits, or both. Facilitatory and inhibitory circuits have been shown to have different roles in motor control (for example: ${ }^{20,21,22}$ ), and might be differentially associated with PD tremor.

Transcranial magnetic stimulation (TMS) is a non-invasive brain stimulation technique that can be used to measure interactions between regions in the cortical motor network, including between SMA and M1 ${ }^{23-25}$. A single-pulse TMS protocol is used to provide a measure of corticospinal excitability: a single suprathreshold TMS pulse delivered to M1 elicits a motorevoked potential (MEP) that is measured from the target muscle using electromyography. A dual-site TMS protocol is used to provide a measure of interactions between SMA and M1: a conditioning stimulus delivered to SMA before a test stimulus delivered to M1 with interstimulus intervals (ISI) of $6 \mathrm{~ms}$ and $7 \mathrm{~ms}$ facilitates the MEP amplitude compared to a test stimulus-alone (single-pulse to M1) ${ }^{23-25,29,30}$, which is likely due to the activation of glutamatergic excitatory interactions between SMA and M1 ${ }^{17,30,31}$. Dual-site TMS reliably measures SMA-M1 connectivity in younger and older adults ${ }^{32}$, but SMA-M1 connectivity has not been characterised in PD. Both SMA and M1 are implicated in resting tremor: singlepulse TMS delivered to SMA and M1 interrupts ongoing tremor activity and resets tremor to a new point in the tremor cycle ${ }^{33}$. Therefore, it is plausible that SMA-M1 connectivity plays a role in PD resting tremor.

In the current study, the primary aim was to examine SMA-M1 connectivity in PD both ON and OFF levodopa dopaminergic medication. An exploratory aim was to examine whether SMA-M1 connectivity was associated with the severity of PD resting tremor ON and OFF levodopa. We hypothesised that the magnitude of SMA-M1 connectivity would be greater 
medRxiv preprint doi: https://doi.org/10.1101/2022.02.22.22270921; this version posted February 24, 2022. The copyright holder for this preprint (which was not certified by peer review) is the author/funder, who has granted medRxiv a license to display the preprint in It is made available under a CC-BY-ND 4.0 International license .

SMA-M1 connectivity in Parkinson's disease

ON than OFF medication, and a reduction in SMA-M1 connectivity in the OFF state would be associated with more severe resting tremor.

\section{Methods}

\section{Participants}

Eighteen people with PD (age range: 54-79 years; disease duration range: 3-13 years) recruited from a local private hospital outpatient clinic participated in this study: Table 1 shows participant characteristics. All participants were screened and excluded if they presented with contraindications to TMS, potential cognitive impairments, and advanced Parkinson's disease progression (see Supplementary Materials section: S1.1.Screening). All participants had a clinical diagnosis of idiopathic PD by a movement disorder neurologist (J.P.R), resting tremor involving at least one upper limb, and were treated with levodopa. Patients with head tremor or severe upper limb dyskinesia were excluded to avoid technical difficulties with stable TMS coil placement. Inclusion and exclusion criteria were assessed by a neurologist (J.P.R) and neuropsychiatrist (B.D.P). The protocol was performed following the Declaration of Helsinki and approved by the Murdoch University Human Research Ethics Committee (2018/117). All participants gave written informed consent before participation. 
Table 1.

Demographic and clinical characteristics of participants.

\begin{tabular}{|c|c|c|c|c|c|c|c|c|}
\hline \multirow[t]{2}{*}{ Participant } & \multirow[t]{2}{*}{ Sex } & \multirow[t]{2}{*}{$\begin{array}{l}\text { H\&Y } \\
\text { score }\end{array}$} & \multirow[t]{2}{*}{$\begin{array}{l}\text { Levodopa } \\
\text { medication }\end{array}$} & \multirow{2}{*}{$\begin{array}{c}\text { Levodopa } \\
\text { dose per } \\
\text { day }\end{array}$} & \multirow[t]{2}{*}{ Other medication } & \multirow{2}{*}{$\begin{array}{c}\text { Levodopa } \\
\text { equivalent daily } \\
\text { dose }^{1}\end{array}$} & \multicolumn{2}{|c|}{$\begin{array}{c}\text { MDS-UPDRS } \\
\text { part III }\end{array}$} \\
\hline & & & & & & & $O N$ & $O F F$ \\
\hline 1 & $\mathrm{M}$ & 2 & $250 \mathrm{mg}$ & 4 & & 1000 & 3 & 2 \\
\hline 2 & M & 1 & $200 \mathrm{mg}$ & 3 & & 600 & 1 & 2 \\
\hline 3 & M & 1 & $200 \mathrm{mg}$ & 3 & $\begin{array}{l}\text { Telmisartan Amlodipini: } \\
\text { blood pressure }\end{array}$ & 600 & 3 & 3 \\
\hline 4 & M & 1 & $100 \mathrm{mg}$ & 3 & $\begin{array}{l}\text { Sifrol ER } 3 \text { mg: PD } \\
\text { symptoms }\end{array}$ & 600 & 1 & 2 \\
\hline 5 & M & 1 & $250 \mathrm{mg}$ & 4 & $\begin{array}{l}\text { Sifrol ER } 3 \text { mg: PD } \\
\text { symptoms } \\
\text { Pariet: stomach acid }\end{array}$ & 1300 & 1 & 5 \\
\hline 6 & M & 1 & $200 \mathrm{mg}$ & 3 & & 600 & 1 & 1 \\
\hline 7 & M & 1 & $200 \mathrm{mg}$ & 3 & $\begin{array}{l}\text { Sifrol ER } 4.5 \text { mg: PD } \\
\text { symptoms } \\
\text { Progout: gout } \\
\text { Atacand: blood pressure } \\
\text { Flomaxtra: unitary relief } \\
\text { Lipitor: cholesterol }\end{array}$ & 1050 & 5 & 2 \\
\hline 8 & $\mathrm{~F}$ & 1 & $125 \mathrm{mg}$ & 3 & $\begin{array}{l}\text { Pramipexole } 1.5 \mathrm{mg} \text { : PD } \\
\text { symptoms }\end{array}$ & 525 & 2 & 3 \\
\hline
\end{tabular}


SMA-M1 connectivity in Parkinson's disease

\begin{tabular}{|c|c|c|c|c|c|c|c|c|}
\hline 9 & $\mathrm{M}$ & 3 & $200 \mathrm{mg}$ & 3 & & 600 & 7 & 6 \\
\hline 10 & $\mathrm{M}$ & 1 & $100 \mathrm{mg}$ & 3 & & 300 & 6 & 5 \\
\hline 11 & $\mathrm{M}$ & 1 & $250 \mathrm{mg}$ & 2 & $\begin{array}{l}\text { Somac: heartburn } \\
\text { Atozet: cholesterol }\end{array}$ & & 3 & 4 \\
\hline 12 & $\mathrm{~F}$ & 2 & $100 \mathrm{mg}$ & 2 & $\begin{array}{l}\text { Sifrol ER } 1.5 \text { mg: PD } \\
\text { symptoms }\end{array}$ & 250 & 3 & 7 \\
\hline 13 & $\mathrm{M}$ & 1 & $100 \mathrm{mg}$ & 3 & $\begin{array}{l}\text { Azilect } 1 \text { mg: PD } \\
\text { symptoms }\end{array}$ & 400 & 2 & 4 \\
\hline 14 & $\mathrm{M}$ & 1 & $200 \mathrm{mg}$ & 4 & $\begin{array}{l}\text { Acimax: stomach acid } \\
\text { Co-diovan: blood pressure }\end{array}$ & 800 & 2 & 2 \\
\hline 15 & $\mathrm{~F}$ & 1 & $50 \mathrm{mg}$ & 3 & $\begin{array}{l}\text { Sifrol ER } 3 \text { mg: PD } \\
\text { symptoms } \\
\text { Ramipril: blood pressure }\end{array}$ & 450 & 3 & 5 \\
\hline 16 & $\mathrm{M}$ & 1 & $100 \mathrm{mg}$ & 3 & & 300 & 1 & 1 \\
\hline 17 & $\mathrm{~F}$ & 2 & $200 \mathrm{mg}$ & 3 & $\begin{array}{l}\text { Sifrol ER } 1.5 \text { mg: PD } \\
\text { symptoms }\end{array}$ & 750 & 1 & 5 \\
\hline 18 & $\mathrm{M}$ & 1 & $250 \mathrm{mg}$ & 3 & $\begin{array}{l}\text { Sifrol ER } 1.5 \text { mg: PD } \\
\text { symptoms }\end{array}$ & 900 & 1 & 2 \\
\hline
\end{tabular}

F, female; M, male; PD, Parkinson's disease; H\&Y, Hoehn \& Yahr; 1, a sum of each Parkinsonian medication converted into levodopa equivalent dose ${ }^{6} ; 2$, sum of tremor scores from the MDS-UPDRS subitems for resting tremor amplitude (item 17) and constancy (item 18) in the affected upper-limb. 
medRxiv preprint doi: https://doi.org/10.1101/2022.02.22.22270921; this version posted February 24, 2022. The copyright holder for this preprint (which was not certified by peer review) is the author/funder, who has granted medRxiv a license to display the preprint in

SMA-M1 connectivity in Parkinson's disease

\section{TMS}

During the TMS procedure, participants were seated in a comfortable chair with both of their forearms resting on the arms of the chair. Electromyographic (EMG) activity was recorded from the relaxed first dorsal interosseous (FDI) of the hand and the extensor carpi radialis (ECR) of the forearm of the most affected arm using Ag-AgCI surface electrodes placed in a belly-tendon montage ${ }^{34}$. EMG activity was amplified using a CED 1902 at a gain of 1000, bandpass filtered at 5-1000 Hz, and digitised using a CED 1401 with a sampling rate of 5 kHz. Dual-site TMS was delivered using two figure-of-eight coils (50-mm diameter), each connected to a Magstim 200 stimulator (Magstim Co., Whitland, Dyfed, UK).

Neuronavigation software (Brainsight TMS, Rogue Research, Montreal, Canada) was used to monitor coil positioning in both sessions.

The procedure for M1 stimulation is reported in the Supplementary Materials (see S1.2.MI stimulation site). SMA stimulation was delivered with the coil placed on the midline using a lateral orientation (see Figure 1B in main manuscript; ${ }^{5,6-9}$ ). The site of SMA stimulation was $4 \mathrm{~cm}$ anterior to $\mathrm{Cz}$, which is the midpoint between the nasion-inion and interaural plane $\mathrm{Cz}$ as defined by the International 10-20 System; ${ }^{5,6,9}$.

\section{$\mathrm{SI}_{1 \mathrm{mV}}$ intensity, $\mathrm{SI}_{1 \mathrm{mv}}$-alone MEP, AMT}

M1 TMS intensity was set as the intensity (as a percentage of maximum stimulator output; \%MSO) that elicited peak-to-peak MEP amplitudes of $\sim 1 \mathrm{mV}$ in the resting FDI, defined as ' $\mathrm{SI}_{1 \mathrm{mV}}$ '23-25,29,32. MEP amplitude elicited from single-pulse trials using the $\mathrm{SI}_{1 \mathrm{mV}}$ intensity delivered to M1 was defined as ' $\mathrm{SI}_{1 \mathrm{mV}}$-alone' MEP amplitude (see Figure 1A). Active motor threshold (AMT) was defined as the minimum TMS intensity (\%MSO) that elicited MEPs in the FDI of at least $0.2 \mathrm{mV}$ from at least five out of ten consecutive trials during an isometric 
medRxiv preprint doi: $h$ ttps://doi.org/10.1101/2022.02.22.22270921; this version posted February 24, 2022. The copyright holder for this preprint (which was not certified by peer review) is the author/funder, who has granted medRxiv a license to display the preprint in It is made available under a CC-BY-ND 4.0 International license.

SMA-M1 connectivity in Parkinson's disease

contraction of $10 \%$ maximum voluntary contraction ${ }^{35}$. AMT was used to set the intensity of SMA stimulation. TMS intensities were determined in both sessions. The analyses performed to examine differences in TMS parameters are reported in the Supplementary Materials (see S1.3.1.Data analysis; S1.3.2.Results).

\section{Experimental Protocol}

Figure 1E shows the experimental procedure. Each participant completed two 2-hour experimental sessions: one session $\mathrm{ON}$, defined as starting the experimental session within one hour of taking levodopa (range: 60-75 minutes), and one session OFF, defined as starting the experimental session a minimum of 12 hours after overnight withdrawal from dopaminergic medication (range: 12-15.5 hours). The sessions were counterbalanced across participants, separated by at least 7 days (first session was on average $7.67 \pm 1.45$ days before the second session), and completed in the morning (range: 6:00-10.30 a.m.) to coincide with the individual patient dosing times and to allow for a minimum 12-hour withdrawal from medication. 
medRxiv preprint doi: https://doi.org/10.1101/2022.02.22.22270921; this version posted February 24, 2022. The copyright holder for this preprint (which was not certified by peer review) is the author/funder, who has granted medRxiv a license to display the preprint in

SMA-M1 connectivity in Parkinson's disease

(A) $\mathrm{Sl}_{1 \mathrm{mV}}$-alone coil placement

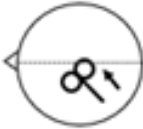

optimal M1 site to elicit $\sim 1 \mathrm{mV}$

MEP amplitude in the resting

FDI

(C) $\mathrm{SI}_{1 \mathrm{mv}}$-alone trial

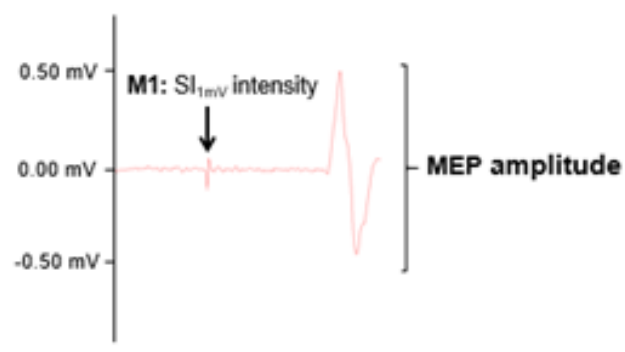

(B) Dual-site coil placement

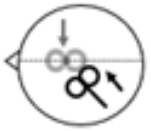

SMA stimulation site

$4 \mathrm{~cm}$ anterior to $\mathrm{Cz}$

(D) Dual-site trial

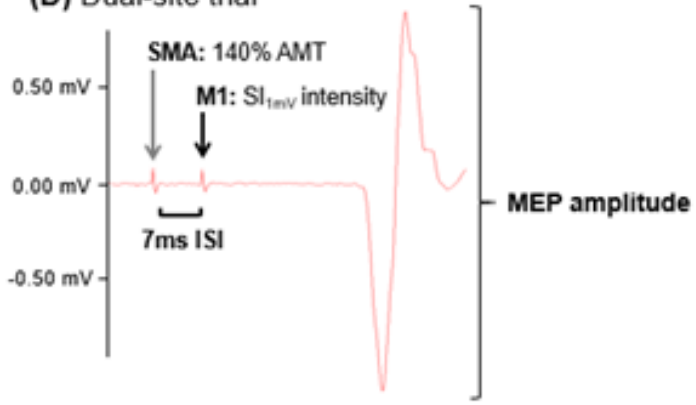

SMA-M1 connectivity: the mean dual-site MEP amplitude as a ratio of the mean Sl1mv-alone MEP amplitude.

(E) Experimental procedure for session 1 and session 2

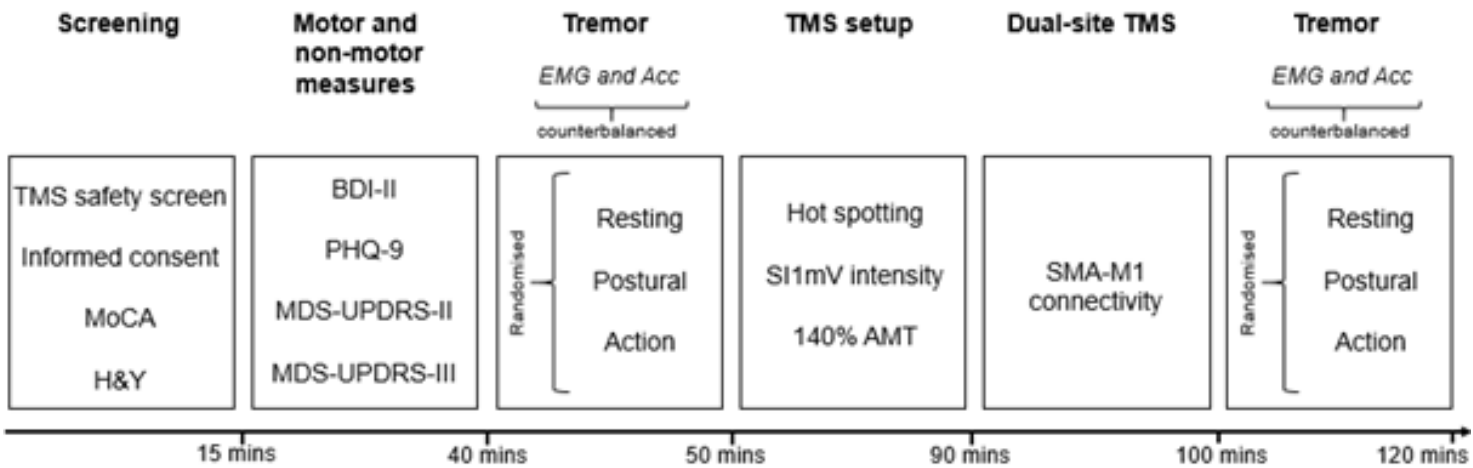

M1, primary motor cortex; MEP, motor evoked potential; FDI, first dorsal interosseous; SMA, supplementary motor area; SI1mV. stimulation intensity; SI1mV-alone, stimulation intensity that elicited $\sim 1 \mathrm{mV}$ peak-to-peak MEPS; ISI, inter-stimulus interval; MoCA Montreal Cognitive Assessment; H\&Y, Hoehn \& Yahr Scale; BDI, Beck Depression Index, PHQ, Patient Health Questionnaire MDS-UPDRS, Movement Disorder Society-Unified PD Rating Scale; EMG, electromyography; Acc, accelerometer

Figure 1. SMA-M1 connectivity was assessed by delivering $\mathrm{SI}_{1 \mathrm{mV}}$-alone and dual-site trials. Panel A shows the coil placement and current flow direction (indicated by the arrow) for SI $1 \mathrm{mv}$-alone trials delivered to M1, and Panel $\mathrm{C}$ shows an example MEP elicited by SI $1 \mathrm{mv}$-alone trials to M1 ( 1mV MEP amplitude). Panel B shows the coil placement for dual-site trials: the grey coil represents the SMA stimulation site, and the black coil represents the M1 stimulation site, with arrows indicating current flow direction. The site of SMA stimulation was $4 \mathrm{~cm}$ anterior to $\mathrm{Cz}$; this site has been shown to correspond to the anatomical representation of SMA identified using individual structural MRI in younger adults ${ }^{5,6}$. Panel D shows an example MEP amplitude elicited by dual-site TMS which involves delivering a conditioning stimulus to SMA (140\% AMT) $7 \mathrm{~ms}$ before a test stimulus to M1. All measures were obtained from the tremoraffected limb. EMG and tri-axial accelerometer measures of tremor were counterbalanced across sessions and participants. SMA-M1 connectivity was quantified as the mean dual-site MEP amplitude as a ratio of the mean $\mathrm{SI}_{1 \mathrm{mv}}$-alone MEP amplitude. Panel $E$ shows the experimental procedure for $\mathrm{ON}$ and OFF medication: experimental sessions were separated by a minimum of 7 days. 
medRxiv preprint doi: https://doi.org/10.1101/2022.02.22.22270921; this version posted February 24, 2022. The copyright holder for this preprint (which was not certified by peer review) is the author/funder, who has granted medRxiv a license to display the preprint in It is made available under a CC-BY-ND 4.0 International license .

SMA-M1 connectivity in Parkinson's disease

\section{SMA-M1 connectivity}

SMA-M1 connectivity was assessed by delivering $\mathrm{SI}_{1 \mathrm{mV}}$-alone (see Figure $1 \mathrm{~A}$ ) and dual-site trials (see Figure 1B). For dual-site trials, a conditioning pulse delivered to SMA (140\% AMT) preceded a test pulse delivered to $\mathrm{M} 1\left(\mathrm{SI}_{1 \mathrm{mV}}\right)$ by an inter-stimulus interval (ISI) of 7 ms. Dual-site TMS measures of SMA-M1 connectivity have been shown to be moderately reliable using an ISI of $7 \mathrm{~ms}$ in younger and older adults ${ }^{32}$. The timing of the TMS pulses was controlled using a custom-developed Signal software (version 6.02) script and the digital output of a Cambridge Electronic Design analogue-digital converter (Micro 1401). The custom-developed Signal script triggered $\mathrm{SI}_{1 \mathrm{mV}}$-alone and dual-site TMS pulses if EMG activity was below an individually determined EMG activity threshold for $50 \mathrm{~ms}$, indicating no tremor at the time of TMS delivery (see Figure 2A). If EMG activity was not below the EMG activity threshold for $50 \mathrm{~ms}$, TMS triggered after $\sim 5$ seconds $( \pm 2 \%)$, indicating some EMG activity at the time of TMS delivery (see Figure 2B): these trials were excluded from the analysis. See Supplementary Materials for more details of the custom-developed Signal script (see S1.4.Custom-developed script). Signal software was also used to pseudorandomise trial conditions with an inter-trial interval of $5 \mathrm{~s}( \pm 10 \%)$. 
medRxiv preprint doi: $h$ ttps://doi.org/10.1101/2022.02.22.22270921; this version posted February 24, 2022. The copyright holder for this preprint (which was not certified by peer review) is the author/funder, who has granted medRxiv a license to display the preprint in It is made available under a CC-BY-ND 4.0 International license.

SMA-M1 connectivity in Parkinson's disease

(A) TMS delivered after a window of $50 \mathrm{~ms}$ below a defined threshold.

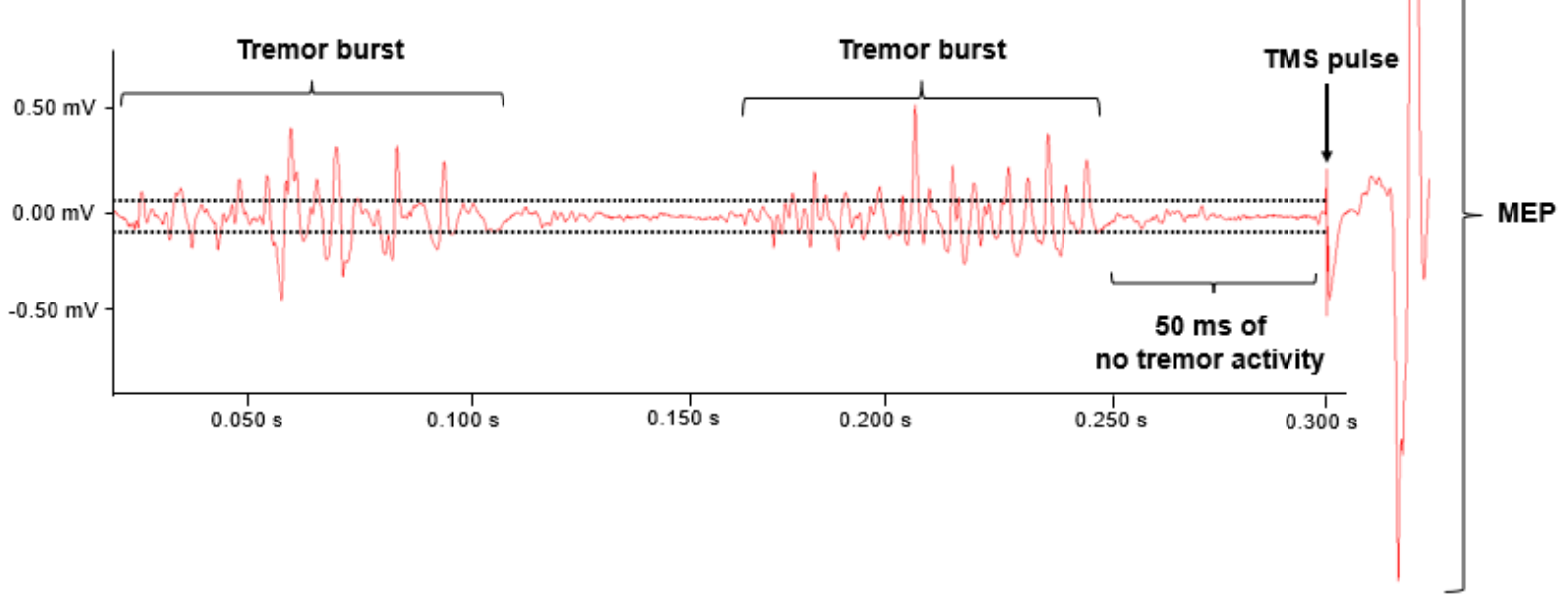

(B) TMS delivered after a period of $\sim 5 \mathrm{~s}$ without a window of $50 \mathrm{~ms}$ below a defined threshold.

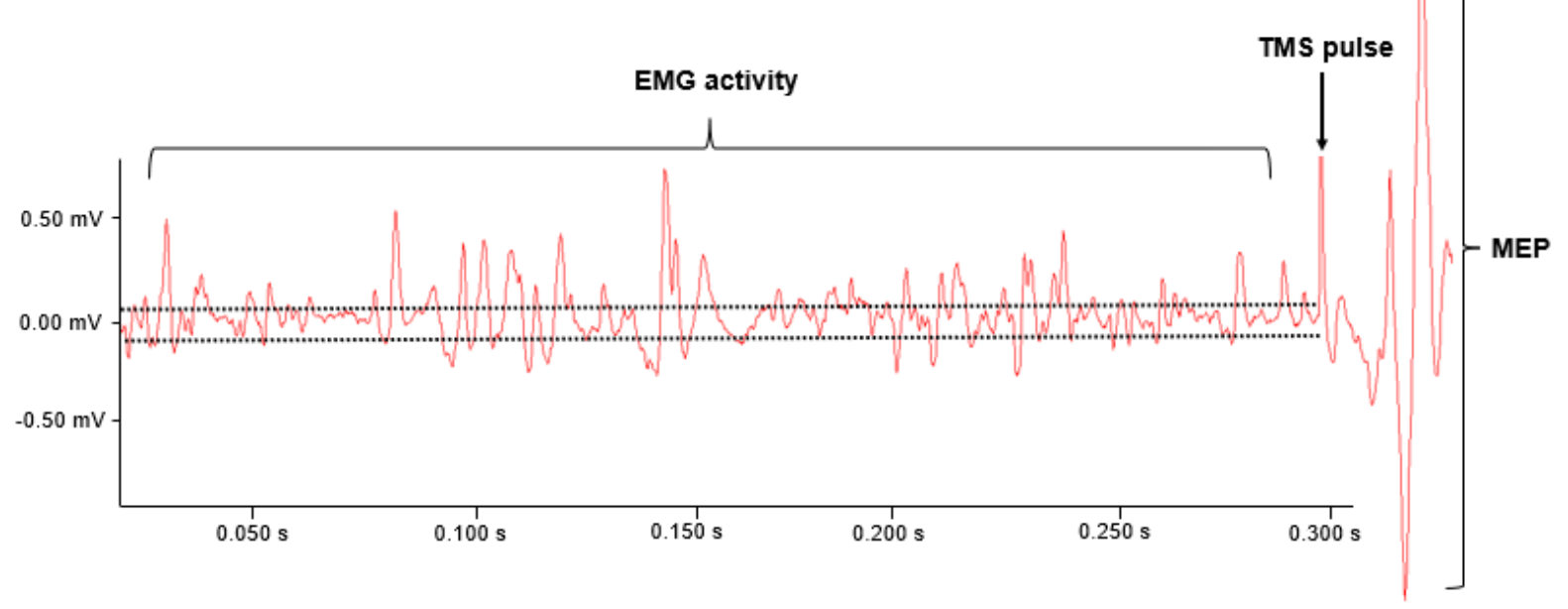

Figure 2. Example EMG traces from a participant OFF medication. SI1mv-alone and dual-site trials were delivered after $50 \mathrm{~ms}$ of EMG activity below an EMG activity threshold determined for each participant (A) or if a period of $\sim 5$ seconds passed without EMG activity below the determined EMG activity threshold (B; these trials were removed from analysis). (B) shows the last 0.300 seconds of the 5 second period. The two horizontal dotted lines reflect the predetermined threshold; EMG activity within these lines indicates resting EMG activity (indicative of the absence of tremor). Thresholds (i.e., peak amplitudes; $\mathbf{m V}$ ) were established for each participant before TMS.

Two experimental blocks each consisting of 30 trials were delivered: $15 \mathrm{SI}_{1 \mathrm{mV}}$-alone trials (delivered to M1) and 15 dual-site trials. Blocks lasted 4 minutes with a 1-2-minute break 
medRxiv preprint doi: https://doi.org/10.1101/2022.02.22.22270921; this version posted February 24, 2022. The copyright holder for this preprint (which was not certified by peer review) is the author/funder, who has granted medRxiv a license to display the preprint in

SMA-M1 connectivity in Parkinson's disease

between the blocks. Participants were instructed to remain quiet, not supress tremor activity, keep their eyes open and stay awake and alert during the experimental blocks ${ }^{36,37}$. SMA-M1 connectivity was quantified by expressing the mean dual-site MEP amplitude as a ratio of the mean $\mathrm{SI}_{1 \mathrm{mV}}$-alone MEP amplitude. Ratios greater than 1.0 indicate a facilitatory effect of SMA stimulation on M1, whereas ratios less than 1.0 indicate an inhibitory effect of SMA stimulation on M1. Although stimulation parameters were optimised for the FDI, MEPs were simultaneously recorded from both FDI and ECR and, therefore, SMA-M1 connectivity was quantified separately from FDI and ECR MEPs.

\section{Measures of PD tremor}

Resting, postural and action tremor were measured using the Movement Disorder Society Unified Parkinson's Disease Rating Scale (MDS-UPDRS), a tri-axial accelerometer, and EMG, and recorded from the most affected upper limb ( $n=4$ left arm). Measures of resting tremor are reported here and measures of postural and action tremor are reported in the Supplementary Materials (see S2.Postural and action tremor). For resting tremor, participants were instructed to relax their forearm on the armrest of the chair without their hand touching the chair or their knee. MDS-UPDRS was assessed at the beginning of each session and completed $\sim 35$ minutes before TMS setup began. EMG and accelerometer measures of tremor were assessed $\sim 5$ minutes before and again $\sim 5$ minutes after TMS blocks to identify whether tremor changed throughout the two-hour experimental session.

\section{MDS-UPDRS}

Items 17 and 18 from the MDS-UPDRS part III were used to assess the severity of resting tremor using a 5-point scale (0: normal, 1: slight, 2: mild, 3: moderate, 4: severe) ${ }^{38}$. The MDS-UPDRS was rated by the experimenter (certified MDS-UPDRS assessor). 
medRxiv preprint doi: https://doi.org/10.1101/2022.02.22.22270921; this version posted February 24, 2022. The copyright holder for this preprint (which was not certified by peer review) is the author/funder, who has granted medRxiv a license to display the preprint in

SMA-M1 connectivity in Parkinson's disease

\section{EMG tremor}

Surface EMG was used to measure the muscular activity involved in tremor and was recorded from the FDI, ECR and flexor carpi radialis (FCR) using Ag-AgCI surface electrodes placed in a belly-tendon montage ${ }^{34}$. The EMG signal was amplified (x1000; CED 1902 amplifier), bandpass filtered $(10-500 \mathrm{~Hz})$ and digitized at a sampling rate of $5 \mathrm{kHz}(\mathrm{CED} 1401$ interface).

\section{Acceleration tremor}

A tri-axial accelerometer (Arduino GY-61 ADXL335; length: 21mm; width: $15 \mathrm{~mm}$; height $11 \mathrm{~mm})$ was used to measure tremor changes in acceleration in three dimensions $(\mathrm{x}, \mathrm{y}$, and $\mathrm{z}$ planes) and was placed on the proximal phalanx of the index finger, which was secured to the finger with tape. The accelerometry signal was amplified (x1000; CED 1902 amplifier), bandpass filtered $(2-30 \mathrm{~Hz})$ and digitized at a sampling rate of $5 \mathrm{kHz}$ (CED 1401 interface). Acceleration was not measured for two participants because of technical issues with the accelerometer.

\section{Data processing and analysis}

All analyses were performed using R (version 4.1.0). Shapiro-Wilk's test for normality was violated for one condition: SMA-M1 connectivity OFF. Normality was assumed for all $t$-tests and ANOVAs given that these analyses are robust to moderate violations of normality ${ }^{39}$. Mauchly's test of sphericity was not violated and, therefore, sphericity was assumed. Unless stated otherwise, all tests were two-tailed, values are expressed as mean and standard deviation, and statistical significance was accepted at an alpha level of $P<0.05$.

\section{Resting tremor}


medRxiv preprint doi: https://doi.org/10.1101/2022.02.22.22270921; this version posted February 24, 2022. The copyright holder for this preprint (which was not certified by peer review) is the author/funder, who has granted medRxiv a license to display the preprint in It is made available under a CC-BY-ND 4.0 International license.

SMA-M1 connectivity in Parkinson's disease

Paired-sample $t$-tests were performed to examine differences in the MDS-UPDRS resting tremor severity score ON and OFF medication. Repeated-measures ANOVAs were performed to examine differences in mean EMG amplitude $(\mathrm{mV})$ between muscles (withinsubject factor: FDI, ECR, FCR), medication state (within-subject factor: ON, OFF) and time (within-subject factor: before TMS, after TMS). Repeated-measures ANOVAs were also performed to examine differences in mean acceleration amplitude $\left(\mathrm{m} / \mathrm{s}^{2}\right)$ between medication state (within-subject factor: ON, OFF) and time (within-subjects factor: before TMS, after TMS).

\section{Relationship between resting tremor and SMA-M1 connectivity}

As a first step to examine the role of SMA-M1 connectivity in PD resting tremor, exploratory Pearson's product-moment correlation coefficients were performed to examine the relationship between SMA-M1 connectivity (FDI, ECR) and tremor measures (EMG, acceleration). This was performed separately for medication (ON, OFF), tremor measures (before and after TMS), SMA-M1 connectivity recorded from FDI and EMG recorded from FDI and SMA-M1 connectivity recorded from ECR and EMG recorded from the ECR.

\section{Data availability}

The data supporting the findings of this study are available from the corresponding author upon reasonable request.

\section{Results}

\section{Resting tremor}

Figure 3 shows column scatter plots of MDS-UPDRS (Fig 3A), mean EMG amplitude (mV;

Fig 3B) and mean acceleration amplitude $\left(\mathrm{m} / \mathrm{s}^{2}\right.$; Fig 3C) for resting tremor ON and OFF 
medRxiv preprint doi: https://doi.org/10.1101/2022.02.22.22270921; this version posted February 24, 2022. The copyright holder for this preprint (which was not certified by peer review) is the author/funder, who has granted medRxiv a license to display the preprint in It is made available under a CC-BY-ND 4.0 International license .

SMA-M1 connectivity in Parkinson's disease

medication. Paired-sample $t$-tests showed a significant difference in resting tremor severity scores measured using MDS-UPDRS ON and OFF medication $\left(t_{17}=-3.25, P=0.005, d=0.77\right)$. A repeated-measures ANOVA performed on mean EMG amplitude showed no significant main effect of Time $\left(\mathrm{F}_{1,17}=0.68, P=0.420, \eta_{\mathrm{p}}{ }^{2}=0.04\right)$, Medication $\left(\mathrm{F}_{1,17}=1.19, P=0.291\right.$, $\left.\eta_{\mathrm{p}}{ }^{2}=0.07\right)$, Muscle $\left(\mathrm{F}_{2,17}=3.40, P=0.057, \eta_{\mathrm{p}}{ }^{2}=0.17\right)$, and no significant interactions (all $\mathrm{F}<2.68$, all $P>0.120$, all $\left.\eta_{\mathrm{p}}^{2}<0.14\right)$. A repeated-measures ANOVA performed on the mean acceleration amplitude showed no significant main effect of Time $\left(\mathrm{F}_{1,15}=2.77, P=0.117\right.$, $\left.\eta_{\mathrm{p}}{ }^{2}=0.16\right)$, Medication $\left(\mathrm{F}_{1,15}=0.25, P=0.621, \eta_{\mathrm{p}}{ }^{2}=0.02\right)$, and no significant Time* Medication interaction $\left(\mathrm{F}_{1,15}=0.12, P=0.732, \eta_{\mathrm{p}}^{2}=0.01\right)$. 
medRxiv preprint doi: $h$ ttps://doi.org/10.1101/2022.02.22.22270921; this version posted February 24, 2022. The copyright holder for this preprint (which was not certified by peer review) is the author/funder, who has granted medRxiv a license to display the preprint in perpetuity.

SMA-M1 connectivity in Parkinson's disease

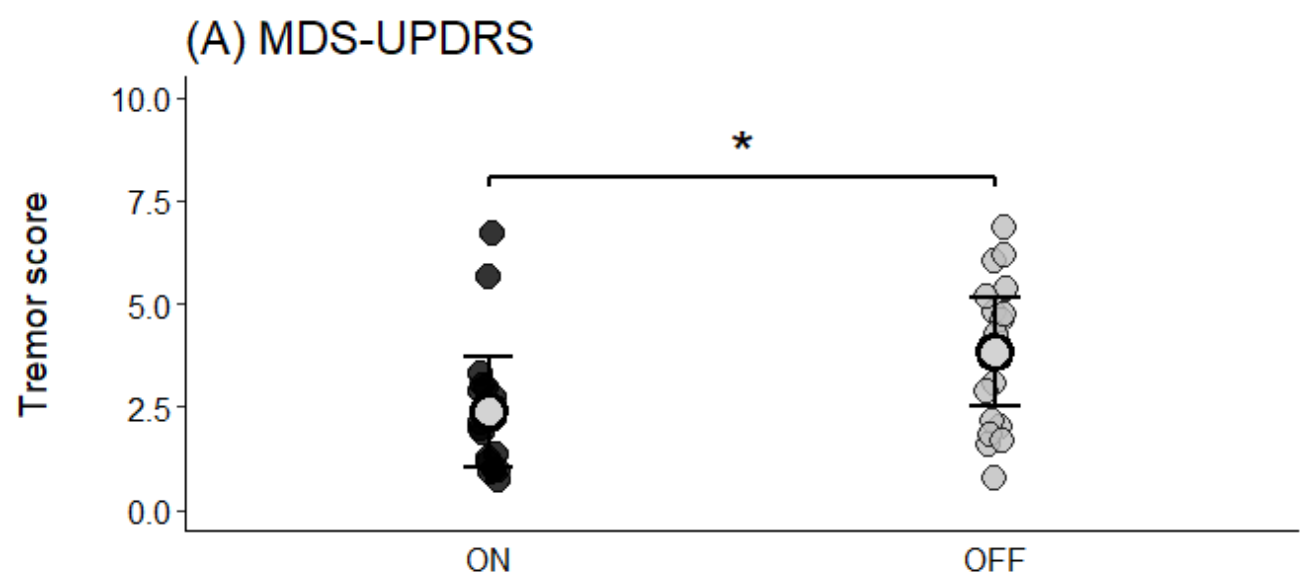

(B) EMG
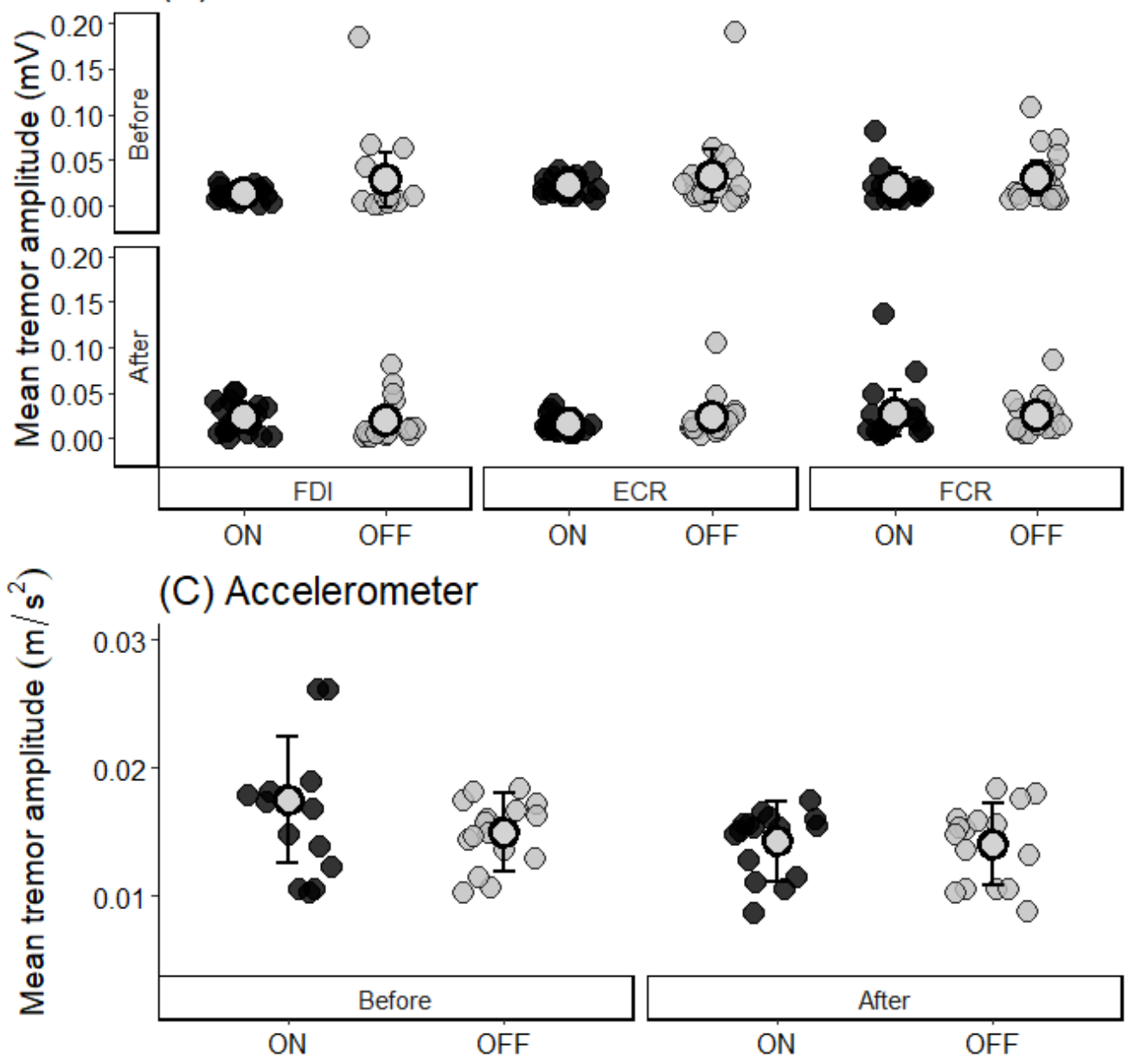

Figure 3. Resting tremor recorded from the MDS-UPDRS tremor severity score (A), EMG mean amplitude $(\mathrm{mV})(\mathrm{B})$, and acceleration mean amplitude $\left(\mathrm{m} / \mathrm{s}^{2}\right)$ ON (black circles) and OFF (grey circles) medication. EMG and acceleration were measured before and after TMS. $* P<0.05$.

\section{SMA-M1 connectivity}


medRxiv preprint doi: $h$ ttps://doi.org/10.1101/2022.02.22.22270921; this version posted February 24, 2022. The copyright holder for this preprint (which was not certified by peer review) is the author/funder, who has granted medRxiv a license to display the preprint in

SMA-M1 connectivity in Parkinson's disease

Figure 4 shows SMA-M1 connectivity ratios quantified from FDI MEPs (Figure 4A) and ECR MEPs (Figure 4B). Paired-samples $t$-tests showed that SMA-M1 connectivity ratios were significantly greater ON than OFF medication for FDI $\left(t_{17}=2.39, P=0.029, d=0.56\right)$ and ECR $\left(t_{17}=3.43, P=0.003, d=0.81\right)$. ON medication, SMA-M1 connectivity ratios were not significantly different from 1.0 when quantified from FDI MEPs $\left(t_{17}=0.51, P=0.62, d=0.25\right)$ or ECR MEPs $\left(t_{17}=1.89, P=0.077, d=0.18\right)$. OFF medication, SMA-M1 connectivity ratios from both FDI MEPs $\left(t_{17}=-4.57, P<0.001, d=0.25\right)$ and ECR MEPs $\left(t_{17}=-4.03, P=0.001\right.$, $d=0.20$ ) were significantly smaller than 1.0 , suggesting a conditioning stimulus to SMA had an inhibitory influence on M1 excitability when individuals were OFF medication.

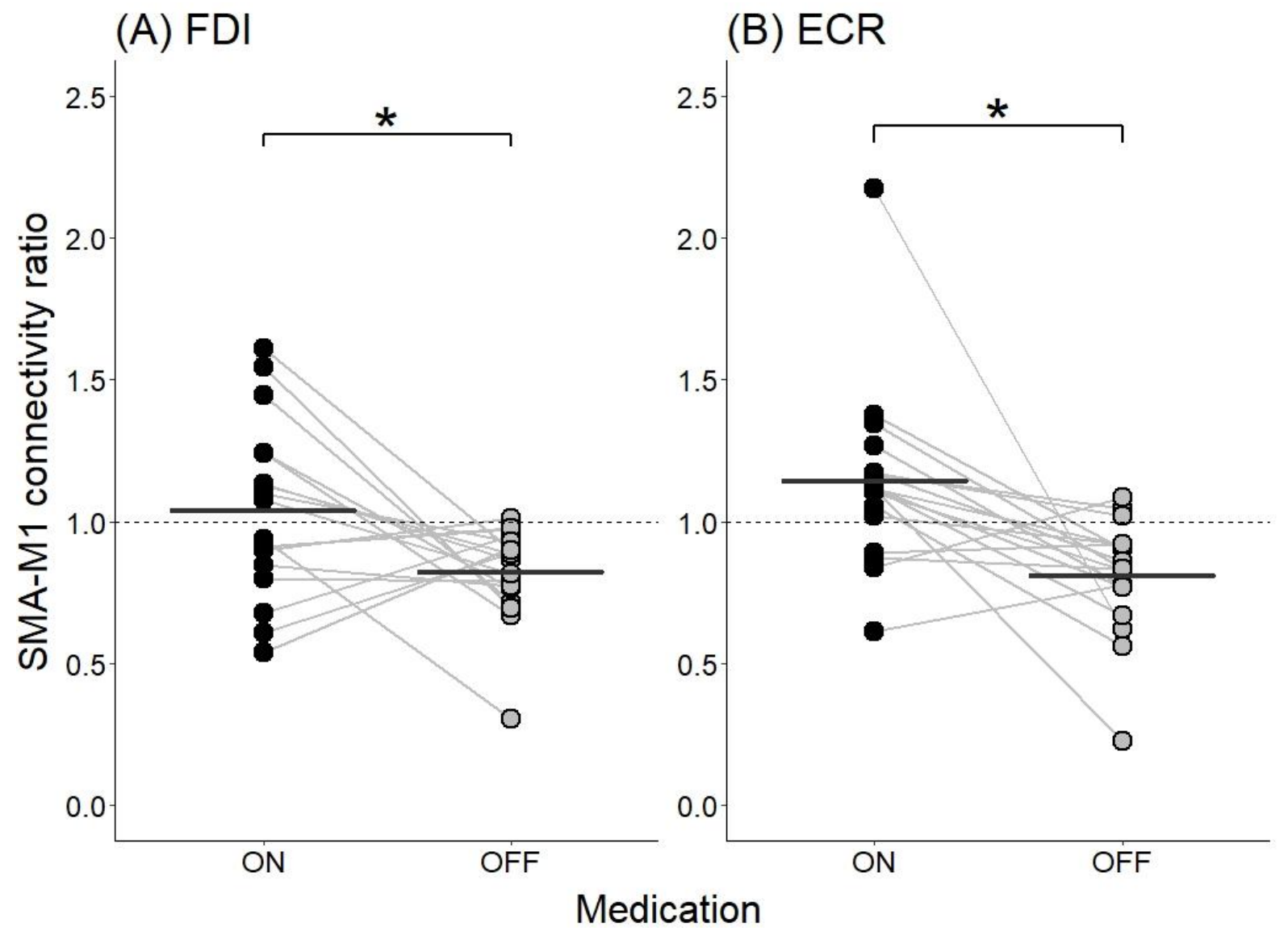

Figure 4. Column scatterplots show SMA-M1 connectivity quantified from FDI MEPs (A) and ECR MEPs (B) ON (black circles) and OFF medication (grey circles). SMA-M1 ratios greater than 1.0 indicate a facilitatory effect of SMA on M1 excitability, whereas SMA-M1 ratios less than 1.0 indicate an inhibitory effect of SMA on M1 excitability. $* P<0.05$. 
medRxiv preprint doi: https://doi.org/10.1101/2022.02.22.22270921; this version posted February 24, 2022. The copyright holder for this preprint (which was not certified by peer review) is the author/funder, who has granted medRxiv a license to display the preprint in It is made available under a CC-BY-ND 4.0 International license .

SMA-M1 connectivity in Parkinson's disease

\section{SMA-M1 connectivity and tremor}

Table 2 shows results for all exploratory correlations performed to examine relationships between SMA-M1 connectivity ratios (FDI, ECR) and mean amplitude (EMG, acceleration) for resting tremor. Figures 5 and 6 show the relationship between SMA-M1 connectivity recorded from FDI and tremor amplitude measured using EMG recorded from FDI (Fig 5) and acceleration (Fig 6). Scatterplots showing (1) ECR SMA-M1 connectivity and resting tremor; (2) FDI and ECR SMA-M1 connectivity and postural and action tremor are presented in the Supplementary Materials (see S3.Relationship between postural and action tremor and SMA-M1 connectivity and S4.Relationship between resting tremor and ECR SMA-M1 connectivity). ON medication, greater FDI SMA-M1 connectivity was significantly associated with less severe tremor amplitude recorded using EMG from FDI (Fig 5) and acceleration (Fig 6) before and after TMS. Additionally, ON medication, greater ECR SMAM1 connectivity was significantly associated with less severe tremor amplitude recorded using EMG from ECR before and after TMS. No other significant associations were found between SMA-M1 connectivity and resting tremor. 
medRxiv preprint doi: https://doi.org/10.1101/2022.02.22.22270921; this version posted February 24, 2022. The copyright holder for this preprint (which was not certified by peer review) is the author/funder, who has granted medRxiv a license to display the preprint in It is made available under a CC-BY-ND 4.0 International license .

SMA-M1 connectivity in Parkinson's disease

Table 2.

Results of correlations between SMA-MI connectivity (FDI, ECR) and resting tremor severity (EMG, acceleration). SMA-M1 connectivity was only correlated with the corresponding muscles recorded using EMG (i.e., FDI SMA-M1 and FDI EMG; ECR SMA-M1 and ECR EMG). Significant correlations are bolded.

Pearson's product-moment correlation coefficients $r$-value ( $P$-value)

\begin{tabular}{|c|c|c|c|c|c|c|c|c|}
\hline & \multicolumn{4}{|c|}{ EMG } & \multicolumn{4}{|c|}{ Acceleration } \\
\hline & \multicolumn{2}{|c|}{$\mathbf{O N}$} & \multicolumn{2}{|c|}{ OFF } & \multicolumn{2}{|c|}{$\mathbf{O N}$} & \multicolumn{2}{|c|}{ OFF } \\
\hline & Before & After & Before & After & Before & After & Before & After \\
\hline$F D I$ & & & & & & & & \\
\hline $\begin{array}{l}\text { SMA-M1 } \\
\text { connectivity }\end{array}$ & $\begin{array}{c}-0.59 \\
(0.001)\end{array}$ & $\begin{array}{c}-0.56 \\
(0.015)\end{array}$ & $\begin{array}{c}0.11 \\
(0.656)\end{array}$ & $\begin{array}{c}0.21 \\
(0.407)\end{array}$ & $\begin{array}{c}-0.74 \\
(0.001)\end{array}$ & $\begin{array}{c}-0.52 \\
(0.037)\end{array}$ & $\begin{array}{c}0.43 \\
(0.096)\end{array}$ & $\begin{array}{c}0.05 \\
(0.861)\end{array}$ \\
\hline$E C R$ & & & & & & & & \\
\hline $\begin{array}{l}\text { SMA-M1 } \\
\text { connectivity }\end{array}$ & $\begin{array}{c}-0.48 \\
(0.042)\end{array}$ & $\begin{array}{c}-0.48 \\
(0.045)\end{array}$ & $\begin{array}{c}0.21 \\
(0.407)\end{array}$ & $\begin{array}{c}0.20 \\
(0.430)\end{array}$ & $\begin{array}{c}-0.12 \\
(0.648)\end{array}$ & $\begin{array}{c}-0.10 \\
(0.701)\end{array}$ & $\begin{array}{c}-0.13 \\
(0.625)\end{array}$ & $\begin{array}{c}-0.19 \\
(0.481)\end{array}$ \\
\hline
\end{tabular}

EMG, electromyography; FDI, first dorsal interosseous; ECR, extensor carpi radialis; Recordings of resting tremor using EMG and acceleration were performed immediately before and after TMS measures. All significant findings are bolded. 
medRxiv preprint doi: $h$ ttps://doi.org/10.1101/2022.02.22.22270921; this version posted February 24, 2022. The copyright holder for this preprint (which was not certified by peer review) is the author/funder, who has granted medRxiv a license to display the preprint in It is made available under a CC-BY-ND 4.0 International license .

SMA-M1 connectivity in Parkinson's disease

Resting tremor measured using EMG

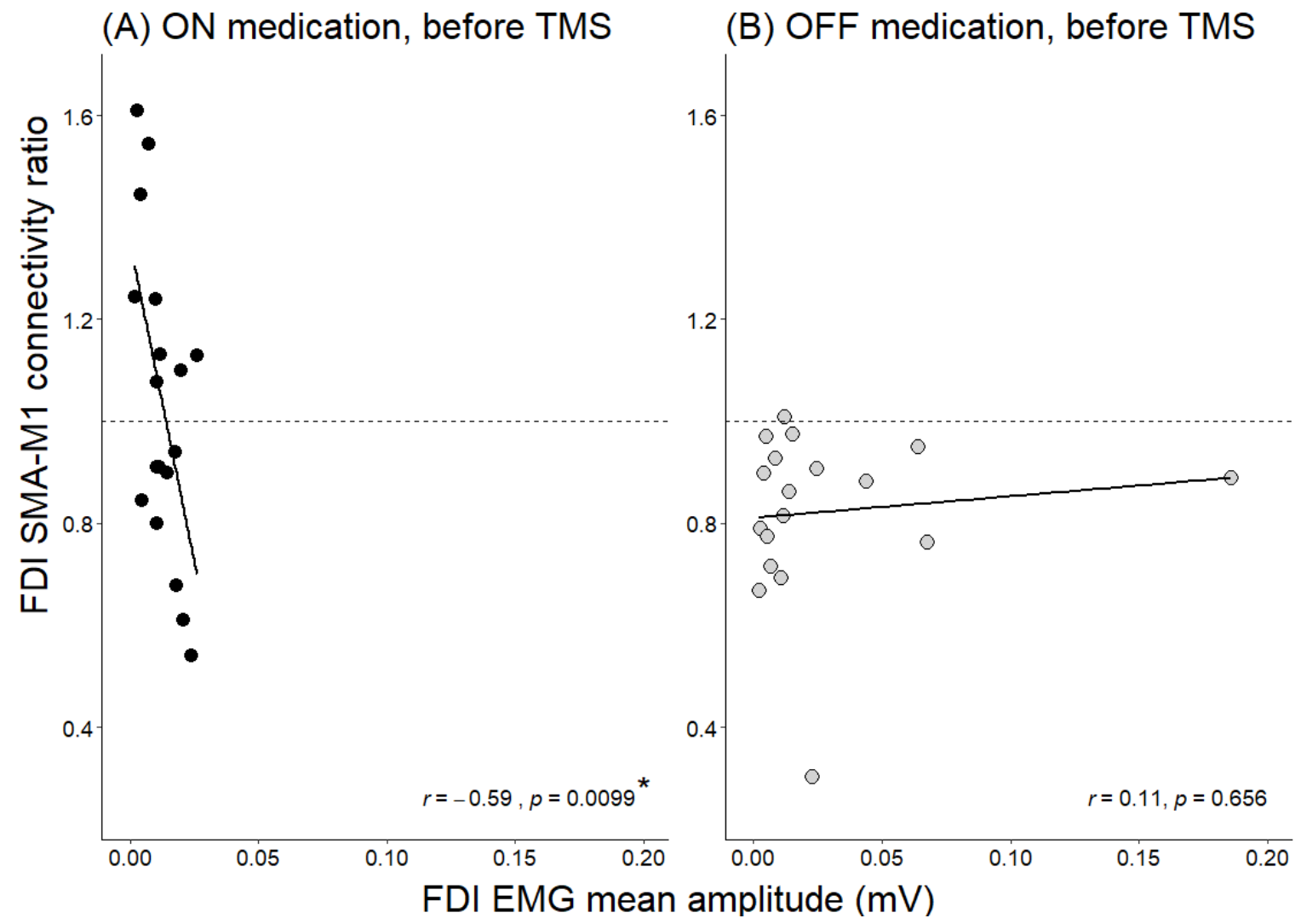

Figure 5. Scatterplots show the relationship between the magnitude of FDI SMA-M1 connectivity ratios and FDI resting tremor amplitude $(\mathrm{mV}) \mathrm{ON}$ medication (A; black circles) and OFF medication (B; grey circles). This figure shows tremor amplitude measured using EMG before but not after TMS, as there was no significant difference in tremor measured at the two time points. $* P<0.05$. 
medRxiv preprint doi: $h$ ttps://doi.org/10.1101/2022.02.22.22270921; this version posted February 24, 2022. The copyright holder for this preprint (which was not certified by peer review) is the author/funder, who has granted medRxiv a license to display the preprint in It is made available under a CC-BY-ND 4.0 International license.

SMA-M1 connectivity in Parkinson's disease

\section{Resting tremor measured using acceleration}

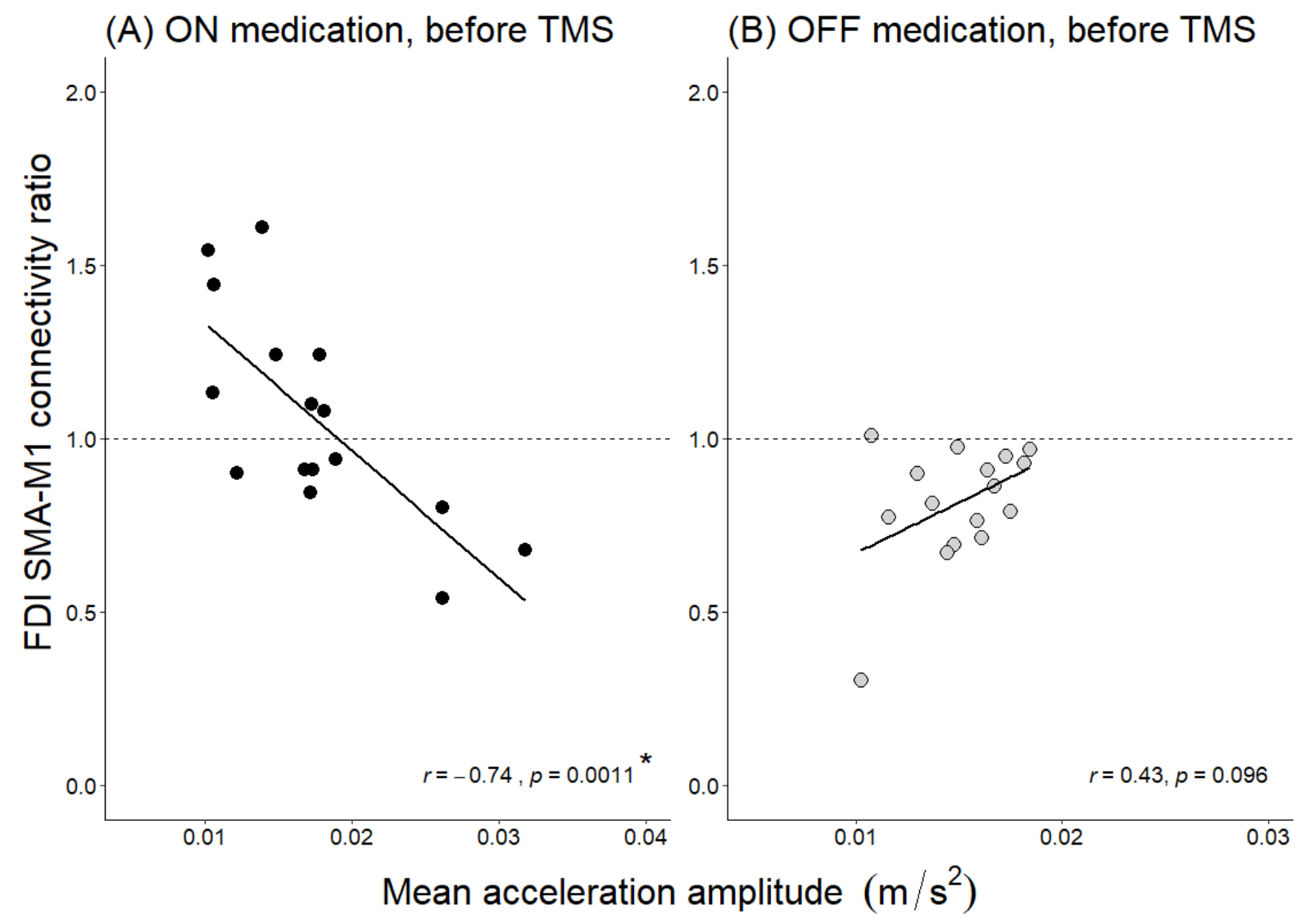

Figure 6. Scatterplots show the relationship between the magnitude of FDI SMA-M1 connectivity ratios and resting tremor acceleration $\left(\mathrm{m} / \mathrm{s}^{2}\right) \mathrm{ON}$ medication (A; black circles) and OFF medication (B; grey circles). This figure shows tremor amplitude measured using acceleration before but not after TMS, as there was no significant difference in tremor measured at the two time points. $* P<0.05$.

\section{Discussion}

The aim of this study was to examine SMA-M1 connectivity using dual-site TMS in people with PD ON and OFF levodopa medication. There were two main findings. First, there was an inhibitory influence of SMA stimulation on M1 excitability OFF medication, which was reduced ON medication. Second, ON medication, individuals who showed SMA-M1 facilitation had reduced tremor amplitude while those with SMA-M1 inhibition had an increased tremor amplitude. 
medRxiv preprint doi: https://doi.org/10.1101/2022.02.22.22270921; this version posted February 24, 2022. The copyright holder for this preprint (which was not certified by peer review) is the author/funder, who has granted medRxiv a license to display the preprint in

SMA-M1 connectivity in Parkinson's disease

\section{OFF medication: Inhibitory influence of SMA on M1 excitability}

This is the first study to measure SMA-M1 connectivity using dual-site TMS in PD. We found that MEP amplitude in FDI was significantly smaller for dual-site stimulation targeting SMA and M1 compared to M1 stimulation alone, suggesting a significant inhibitory influence of SMA stimulation on M1 excitability. Stimulation parameters were optimised for FDI but MEPs were elicited simultaneously from both FDI and ECR (described below); results from ECR show significantly smaller MEP amplitudes for dual-site TMS targeting SMA and M1 compared to M1 stimulation alone, replicating the results found in FDI. This finding of an inhibitory influence of SMA stimulation on M1 excitability in PD OFF medication likely reflects physiological disease-related changes; that is, alterations in the basal ganglia-thalamo-cortical circuit because of a loss in dopaminergic cells. Anatomical studies of non-human primates indicate that the basal ganglia nuclei, namely the internal globus pallidus, have direct connections to SMA ${ }^{14}$. Although dopamine transporter imaging studies show no association between striatal dopamine and PD tremor ${ }^{7,8}$, growing evidence suggests a role of the globus pallidus in the pathophysiology of tremor: a combined EMGfMRI study using dynamic causal modelling showed PD tremor amplitude OFF medication was driven by globus pallidus activity ${ }^{43}$. In addition to SMA receiving direct inhibitory efferent connections from the basal ganglia, studies in non-human primates indicate that SMA also receives efferent input from motor thalamic nuclei targeted by the basal ganglia $14,15,44$, suggesting a basal ganglia-thalamo-SMA circuit. In PD, the main output nuclei within the basal ganglia elicit nett inhibition of the motor thalamic nuclei and decreases cerebral cortex excitability ${ }^{45,46}$. Together, the inhibitory drive from the internal globus pallidus and/or motor thalamic nuclei might reduce SMA excitability and underpin the SMA-M1 inhibition found in the current study. 
medRxiv preprint doi: https://doi.org/10.1101/2022.02.22.22270921; this version posted February 24, 2022. The copyright holder for this preprint (which was not certified by peer review) is the author/funder, who has granted medRxiv a license to display the preprint in

SMA-M1 connectivity in Parkinson's disease

SMA-M1 inhibition found in PD OFF medication might also be due to alterations in the cerebello-thalamo-cortical circuit, which is implicated in tremor-dominant PD ${ }^{43,47,48}$. The cerebellum has anatomical connections to both SMA and M1 via the motor thalamic nuclei 14,49. A diffusion tensor MRI study showed greater neural transmission (measured as an increase in diffusion) along the cerebello-thalamo-cortical white matter tract in tremordominant PD OFF medication compared to healthy controls ${ }^{50}$. fMRI research has shown increased cerebellar BOLD activity in PD OFF medication compared to healthy controls, suggesting hyperactivity within the cerebellum of $\mathrm{PD}^{51,52}$. Increased cerebellar BOLD activity in PD OFF medication fits with dual-site TMS research showing less cerebellothalamo-cortical activity, namely cerebellar brain inhibition, in PD OFF medication compared to healthy controls ${ }^{53-55}$. At the group level, atypical cerebellar facilitation of M1 excitability was found in PD (i.e., cerebellar-M1 ratios greater than 1.0) ${ }^{53-55}$. It is worth noting, however, that poor test re-test reliability of dual-site TMS measures of cerebellar brain inhibition has been reported in older adults ${ }^{56}$ and reliability has not been established in PD. Although speculative, alterations in the cerebello-thalamo-cortical circuit might influence the thalamic inhibitory drive and, subsequently, influence SMA excitability and underpin the SMA-M1 inhibition found in the current study OFF medication.

Altered SMA activity from motor thalamic nuclei (targeted by the basal ganglia and cerebellum) might influence facilitatory and inhibitory intracortical circuits within M1. The influence of SMA on intracortical circuits in M1 could be investigated using a triple TMS pulse protocol ${ }^{57}$ : a conditioning stimulus to SMA preceding paired-pulse TMS to M1 with stimulus parameters set to measure short-interval intracortical inhibition (SICI) and shortinterval intracortical facilitation (SICF). SICI is mediated by $\mathrm{GABA}_{\mathrm{A}}$ receptor activity ${ }^{58,59}$, and SICF reflects the nett result of a complex descending corticospinal volley comprising a 
medRxiv preprint doi: https://doi.org/10.1101/2022.02.22.22270921; this version posted February 24, 2022. The copyright holder for this preprint (which was not certified by peer review) is the author/funder, who has granted medRxiv a license to display the preprint in

SMA-M1 connectivity in Parkinson's disease

series of direct and indirect waves ${ }^{60}$. Results from a triple-pulse TMS study in healthy younger adults showed that a conditioning stimulus to SMA had no influence on the excitability of SICI circuits but increased SICF when compared to TMS given to M1 alone, suggesting that SICF circuits might contribute to the facilitatory effect of SMA stimulation on M1 excitability. There is no research investigating SICF and SICI using paired-pulse TMS in tremor-dominant PD OFF medication and it remains unclear whether the excitability within these circuits is altered compared to healthy controls. However, paired-pulse TMS research examining intracortical excitability in different PD subtypes (e.g., akinetic-rigid symptoms, levodopa-induced dyskinesia, drug-naïve individuals) has shown increased SICF 61-63 and reduced SICI ${ }^{64-67}$ in PD OFF medication compared to healthy age- and sex-matched controls. It is difficult to draw any firm conclusions from previous paired-pulse TMS studies because tremor-dominant PD is thought to have a different pathophysiology to other nontremor PD subtypes ${ }^{68}$ but, based on the above mentioned studies, it is unlikely that SMA-M1 inhibition found in the current study was mediated by intracortical processes in M1.

\section{SMA-M1 connectivity normalised ON compared to OFF medication}

The current study provides the first report of SMA-M1 connectivity in PD both ON and OFF medication: SMA-M1 inhibition OFF medication was reduced ON medication for MEPs measured from both the FDI and ECR. This finding suggests that, at the group level, levodopa 'normalises' the atypical SMA-M1 inhibition observed OFF medication. Evidence from photon emission tomography research showed an increase in SMA cerebral blood flow activity ON compared to OFF medication in patients with PD during simple motor tasks ${ }^{81,82}$. Similarly, fMRI research has shown an increase in BOLD activity in both the SMA and M1 ON compared to OFF medication while performing simple motor tasks, such as an auditorypaced finger-opposition task ${ }^{18,19}$. This is thought to be due to levodopa 'normalising' cortical 
medRxiv preprint doi: https://doi.org/10.1101/2022.02.22.22270921; this version posted February 24, 2022. The copyright holder for this preprint (which was not certified by peer review) is the author/funder, who has granted medRxiv a license to display the preprint in

SMA-M1 connectivity in Parkinson's disease

activity: levodopa increases dopamine levels in the basal ganglia, which reduces nett inhibition of the motor thalamic nuclei and increases excitation of the cerebral cortex ${ }^{45,46}$. Our findings show a similar trend to neuroimaging research; however, it is difficult to make direct comparisons with previous neuroimaging research as these studies investigated nontremor-dominant PD (i.e., akinetic PD) and investigated the effects of medication on cortical activity during motor tasks rather than at rest.

\section{Relationship between SMA-M1 connectivity and resting tremor}

ON medication, SMA-M1 connectivity (FDI, ECR) was weakest in patients with the greatest tremor severity recorded using EMG from both FDI and ECR. This is the first report showing that the excitatory influence of SMA on M1 excitability was associated with tremor ON medication: SMA-M1 facilitation was associated with reduced tremor amplitude, whereas SMA-M1 inhibition was associated with increased tremor amplitude. Both SMA and M1 are implicated in PD resting tremor OFF medication: delivering single-pulse TMS to SMA and M1 interrupts ongoing resting tremor activity and resets tremor to a new point in its cycle ${ }^{33}$. Less is known about the role of SMA or M1 activity ON medication for resting tremor, with most of the neuroimaging and TMS research focusing on neural activity OFF medication. The negative association between SMA-M1 connectivity and resting tremor ON medication in the current study suggests that the magnitude of SMA-M1 facilitation might play a functional role in modulating tremor amplitude.

SMA-M1 connectivity quantified from FDI, but not ECR, was also weakest in patients with the greatest tremor severity recorded using acceleration. It is unclear why SMA-M1 connectivity quantified from FDI was associated with both measures of tremor (EMG, 
medRxiv preprint doi: https://doi.org/10.1101/2022.02.22.22270921; this version posted February 24, 2022. The copyright holder for this preprint (which was not certified by peer review) is the author/funder, who has granted medRxiv a license to display the preprint in

SMA-M1 connectivity in Parkinson's disease

acceleration), but SMA-M1 connectivity quantified from ECR was only associated with one measure of tremor (EMG). In the current study, the stimulation parameters were optimised for FDI and not ECR; it would be interesting to determine whether optimising stimulation parameters for ECR reveals a relationship with both measures of tremor (EMG, acceleration). However, this might not be practical as the cortical target for ECR is closer to the midline than the cortical target for FDI: the two TMS coils used to target SMA and M1 might not fit on the head.

No significant associations were found between SMA-M1 connectivity and tremor severity OFF medication. A previous fMRI study showed increased functional connectivity in SMA and M1 activity in tremor-dominant PD OFF medication compared to healthy controls, and the increase in M1 but not SMA activity was associated with increased clinical resting tremor scores ${ }^{83}$. These findings suggest that alterations in SMA activity OFF medication do not influence resting tremor severity. Our findings, in part, extend this previous research by showing that the excitatory influence of SMA stimulation on M1 excitability OFF medication was not associated with PD resting tremor severity. SMA-M1 inhibition OFF medication might act as a neural substrate for resting tremor such that an individual who shows SMA-M1 inhibition will likely present with resting tremor, but the magnitude of SMA-M1 inhibition is not involved in modulating tremor amplitude.

\section{Limitations}

In the present study, the OFF state was defined as a withdrawal from levodopa for a minimum of 12 hours (range: 12-15.5 hours), which is a sufficient wash-out period for the short-duration effect of levodopa and is consistent with previous research ${ }^{85,88}$. However, some individuals were taking long acting dopaminergic agonist medication $(n=8)$, which 
medRxiv preprint doi: https://doi.org/10.1101/2022.02.22.22270921; this version posted February 24, 2022. The copyright holder for this preprint (which was not certified by peer review) is the author/funder, who has granted medRxiv a license to display the preprint in

SMA-M1 connectivity in Parkinson's disease

requires a withdrawal period of at least 72 hours ${ }^{89}$. Another aspect that we did not control for was the 'wearing-off' effect, whereby levodopa wears off after a few hours and is restored shortly after taking another dose of medication ${ }^{90,91}$. Most participants required a second dose of levodopa in the afternoon $(n=16)$, meaning that these individuals would experience a wearing-off effect $\sim 4$ hours after taking their first dose of levodopa. In the current study, the ON experimental session started one hour after participants took their first dose of levodopa, which meant that single-pulse and dual-site TMS measures of SMA-M1 connectivity were recorded $\sim$ two hours after taking levodopa medication. Even so, effects of levodopa on SMAM1 connectivity might have started to wear off for some of the participants in the current study. Controlling for the withdrawal periods, wearing-off periods, doses, and types of antiparkinsonian drugs is an important consideration for future research.

\section{Conclusions and implications}

This is the first study to characterise SMA-M1 connectivity measured using dual-site TMS in people with PD ON and OFF levodopa medication. Findings from this study suggest that levodopa medication normalises SMA-M1 connectivity ON compared to OFF medication: the inhibitory influence of SMA on M1 excitability found OFF medication was reduced ON medication. ON medication, a facilitatory influence of SMA on M1 excitability was associated with reduced tremor amplitude whereas an inhibitory influence of SMA on M1 excitability was associated with increased tremor amplitude. Together, these findings add to our understanding of neural networks implicated in PD and provide a neurophysiological platform to develop interventions to reduce tremor severity. For example, cortical paired associative stimulation (cPAS) could be used to modulate cortico-cortical activity, as cPAS has previously shown to strengthen connectivity (via long-term potentiation-like plasticity) or weaken connectivity (via long-term depression-like plasticity) between motor brain areas ${ }^{93-}$ 
medRxiv preprint doi: https://doi.org/10.1101/2022.02.22.22270921; this version posted February 24, 2022. The copyright holder for this preprint (which was not certified by peer review) is the author/funder, who has granted medRxiv a license to display the preprint in It is made available under a CC-BY-ND 4.0 International license .

SMA-M1 connectivity in Parkinson's disease

96. cPAS has been used to transiently strengthen the facilitatory connection between SMA and M1 in young adults ${ }^{24}$ and, therefore, cPAS could be used in PD to strengthen SMA-M1 facilitation which might improve tremor severity.

\section{Competing interests}

The authors declare no competing interests and no conflicts of interest.

\section{Author contributions}

This study was performed at Murdoch University, Western Australia, Australia. B.K.R., J.P.R., B.D.P., P.D.D., and A.M.V conceived and designed the experiment; B.K.R. performed the experiments; B.K.R., P.D.D. and A.M.V. analysed the data; B.K.R. drafted the manuscript; P.D.D., and A.M.V. critically revised the manuscript; J.P.R., B.D.P., P.D.D., and A.M.V. provided supervision. All authors have approved the final version of the manuscript and agree to be accountable for all aspects of the work in ensuring that questions related to the accuracy or integrity of any part of the work are appropriately investigated and resolved. All persons designated as authors qualify for authorship, and all those who qualify for authorship are listed.

\section{Funding}

Brittany Rurak was supported by an Australian Government Research Training Program scholarship and the Graduate Women (WA) Inc. Education Trust - Barbara Mary Hale Bursary. Dr Ann-Maree Vallence was supported by an Australian Research Council Discovery Early Career Researcher Award (DE190100694). 
medRxiv preprint doi: https://doi.org/10.1101/2022.02.22.22270921; this version posted February 24, 2022. The copyright holder for this preprint (which was not certified by peer review) is the author/funder, who has granted medRxiv a license to display the preprint in It is made available under a CC-BY-ND 4.0 International license.

SMA-M1 connectivity in Parkinson's disease

\section{Figure legends}

Figure 1. SMA-M1 connectivity was assessed by delivering $\mathrm{SI}_{1 \mathrm{mV}}$-alone and dual-site trials. Panel A shows the coil placement and current flow direction (indicated by the arrow) for $\mathrm{SI}_{1 \mathrm{mv}}$-alone trials delivered to $\mathrm{M1}$, and Panel $\mathrm{C}$ shows an example MEP elicited by SI $1 \mathrm{mv}$-alone trials to M1 ( 1mV MEP amplitude). Panel B shows the coil placement for dual-site trials: the grey coil represents the SMA stimulation site, and the black coil represents the M1 stimulation site, with arrows indicating current flow direction. The site of SMA stimulation was $4 \mathrm{~cm}$ anterior to $\mathrm{Cz}$; this site has been shown to correspond to the anatomical representation of SMA identified using individual structural MRI in younger adults ${ }^{5,6}$. Panel D shows an example MEP amplitude elicited by dual-site TMS which involves delivering a conditioning stimulus to SMA $(140 \%$ AMT) $7 \mathrm{~ms}$ before a test stimulus to M1. All measures were obtained from the tremoraffected limb. EMG and tri-axial accelerometer measures of tremor were counterbalanced across sessions and participants. SMA-M1 connectivity was quantified as the mean dual-site MEP amplitude as a ratio of the mean $\mathrm{SI}_{1 \mathrm{mV}}$-alone MEP amplitude. Panel $E$ shows the experimental procedure for $O N$ and OFF medication: experimental sessions were separated by a minimum of 7 days.

Figure 2. Example EMG traces from a participant OFF medication. SI $1 \mathrm{mv}$-alone and dual-site trials were delivered after $50 \mathrm{~ms}$ of EMG activity below an EMG activity threshold determined for each participant (A) or if a period of $\sim 5$ seconds passed without EMG activity below the determined EMG activity threshold (B; these trials were removed from analysis). (B) shows the last 0.300 seconds of the 5 second period. The two horizontal dotted lines reflect the predetermined threshold; EMG activity within these lines indicates resting EMG activity (indicative of the absence of tremor). Thresholds (i.e., peak amplitudes; $\mathbf{m V}$ ) were established for each participant before TMS.

Figure 3. Resting tremor recorded from the MDS-UPDRS tremor severity score (A), EMG mean amplitude (mV) (B), and acceleration mean amplitude $\left(\mathrm{m} / \mathrm{s}^{2}\right)$ ON (black circles) and OFF (grey circles) medication. EMG and acceleration were measured before and after TMS. $* P<0.05$.

Figure 4. Column scatterplots show SMA-M1 connectivity quantified from FDI MEPs (A) and ECR MEPs (B) ON (black circles) and OFF medication (grey circles). SMA-M1 ratios greater than 1.0 indicate a facilitatory effect of SMA on M1 excitability, whereas SMA-M1 ratios less than 1.0 indicate an inhibitory effect of SMA on M1 excitability. $* P<0.05$.

Figure 5. Scatterplots show the relationship between the magnitude of FDI SMA-M1 connectivity ratios and FDI resting tremor amplitude $(\mathrm{mV}) \mathrm{ON}$ medication (A; black circles) and OFF medication (B; grey circles). This figure shows tremor amplitude 
medRxiv preprint doi: https://doi.org/10.1101/2022.02.22.22270921; this version posted February 24, 2022. The copyright holder for this preprint (which was not certified by peer review) is the author/funder, who has granted medRxiv a license to display the preprint in It is made available under a CC-BY-ND 4.0 International license.

SMA-M1 connectivity in Parkinson's disease

measured using EMG before but not after TMS, as there was no significant difference in tremor measured at the two time points. $* P<0.05$.

Figure 6. Scatterplots show the relationship between the magnitude of FDI SMA-M1 connectivity ratios and resting tremor acceleration $\left(\mathrm{m} / \mathrm{s}^{2}\right) \mathrm{ON}$ medication $(\mathrm{A}$; black circles) and OFF medication (B; grey circles). This figure shows tremor amplitude measured using acceleration before but not after TMS, as there was no significant difference in tremor measured at the two time points. $* P<0.05$.

\section{Table legend}

Table 1.

Demographic and clinical characteristics of participants.

Note. Eighteen individuals participated in this study. Three additional individuals consented to take part in this study but SMA-M1 connectivity could not be obtained because the placement of the two TMS coils on the head was not possible $(n=2)$ or the individual was unable to attend both sessions (n=1); F, female; M, male; PD, Parkinson's disease; H\&Y, Hoehn \& Yahr; 1, a sum of each Parkinsonian medication converted into levodopa equivalent dose ${ }^{6}$; 2 , sum of tremor scores from the MDS-UPDRS subitems for resting tremor amplitude (item 17) and constancy (item 18) in the affected upper-limb.

\section{Table 2.}

Results of correlations between SMA-M1 connectivity (FDI, ECR) and resting tremor severity (EMG, acceleration). SMA-M1 connectivity was only correlated with the corresponding muscles recorded using EMG (i.e., FDI SMA-MI and FDI EMG; ECR SMA-M1 and ECR EMG). Significant correlations are bolded.

Note.EMG, electromyography; FDI, first dorsal interosseous; ECR, extensor carpi radialis; Recordings of resting tremor using EMG and acceleration were performed immediately before and after TMS measures. All significant findings are bolded.

1. Rektorova I. Current treatment of behavioral and cognitive symptoms of Parkinson's disease. Parkinsonism Relat. Disord. Feb 2019;59:65-73.

2. Goetz CG, Tilley BC, Shaftman SR, et al. Movement Disorder Society-Sponsored Revision of the Unified Parkinson's Disease Rating Scale (MDS-UPDRS): Scale Presentation and Clinimetric Testing Results. Mov. Disord. Nov 2008;23(15):2129-2170.

3. Alves G, Forsaa EB, Pedersen KF, Gjerstad MD, Larsen JP. Epidemiology of Parkinson's disease. Journal of Neurology. Sep 2008;255:18-32. 
medRxiv preprint doi: https://doi.org/10.1101/2022.02.22.22270921; this version posted February 24, 2022. The copyright holder for this preprint (which was not certified by peer review) is the author/funder, who has granted medRxiv a license to display the preprint in

SMA-M1 connectivity in Parkinson's disease

4. Duval C. Rest and postural tremors in patients with Parkinson's disease. Brain Research Bulletin. 2006/06/15/ 2006;70(1):44-48.

5. Jankovic J. Parkinson's disease: Clinical features and diagnosis. Journal of Neurology, Neurosurgery and Psychiatry. 2008 2008;79(4):368-376.

6. Lang AE, Lozano AM. Parkinson's disease - First of two parts. N. Engl. J. Med. Oct 1998;339(15):1044-1053.

7. Pirker W. Correlation of dopamine transporter imaging with parkinsonian motor handicap: How close is it? Mov. Disord. 2003;18:S43-S51.

8. Vingerhoets FJG, Schulzer M, Calne DB, Snow BJ. Which clinical sign of Parkinson's disease best reflects the nigrostriatal lesion? Ann. Neurol. 1997;41(1):58-64.

9. Fishman PS. Paradoxical aspects of parkinsonian tremor. Mov. Disord. Jan 2008;23(2):168173.

10. Pogarell $\mathrm{O}$, Gasser T, van Hilten JJ, et al. Pramipexole in patients with Parkinson's disease and marked drug resistant tremor: A randomised, double blind, placebo controlled multicentre study. J. Neurol. Neurosurg. Psychiatry. Jun 2002;72(6):713-720.

11. Leh SE, Ptito A, Chakravarty MM, Strafella AP. Fronto-striatal connections in the human brain: A probabilistic diffusion tractography study. Neurosci. Lett. May 2007;419(2):113-118.

12. Di Martino A, Scheres A, Margulies DS, et al. Functional connectivity of human striatum: A resting state fMRI study. Cereb. Cortex. 2008;18(12):2735-2747.

13. Schell GR, Strick PL. The origin of thalamic inputs to the arcuate premotor and supplementary motor areas. J. Neurosci. 1984;4(2):539-560.

14. Akkal DD. Supplementary motor area and presupplementary motor area: targets of basal ganglia and cerebellar output. The Journal of neuroscience. 2007 2007;27(40):10659-10673.

15. Rouiller EM, Liang F, Babalian A, Moret V, Wiesendanger M. Cerebellothalamocortical and pallidothalamcortical projections to the primary and supplementary motor cortical areas: A multiple tracing study in macaque monkeys J. Comp. Neurol. Jul 1994;345(2):185-213.

16. Dum RP, Strick PL. Motor areas in the frontal lobe of the primate. Physiol. Behav. Dec 2002;77(4-5):677-682.

17. Luppino G, Matelli M, Camarda R, Rizzolatti G. Cortical connections of area F3 (SMA-proper) and area F6 (pre-SMA) in the macaque monkey. J. Comp. Neurol. Dec 1993;338(1):114-140.

18. Buhmann C, Glauche V, Sturenburg HJ, Oechsner M, Weiller C, Buchel C. Pharmacologically modulated $\mathrm{fMRI}$ - Cortical responsiveness to levodopa in drug-naive hemiparkinsonian patients. Brain. Feb 2003;126:451-461.

19. Haslinger $B$, Erhard $P$, Kampfe $N$, et al. Event-related functional magnetic resonance imaging in Parkinson's disease before and after levodopa. Brain. Mar 2001;124:558-570.

20. Ridding MC, Taylor JL, Rothwell JC. The effect of voluntary contraction on corticocortical inhibition in human motor cortex. Journal of Physiology. Sep 1995;487(2):541-548.

21. Reynolds C, Ashby P. Inhibition in the human motor cortex is reduced just before a voluntary contraction. Neurology. Sep 1999;53(4):730-735.

22. Chen $\mathrm{R}, \mathrm{Tam} A$, Butefisch $\mathrm{C}$, et al. Intracortical inhibition and facilitation in different representations of the human motor cortex. Journal of Neurophysiology. Dec 1998;80(6):2870-2881.

23. Arai N, Lu MK, Ugawa Y, Ziemann U. Effective connectivity between human supplementary motor area and primary motor cortex: a paired-coil TMS study. Experimental Brain Research. Jul 2012;220(1):79-87.

24. Arai N, Muller-Dahlhaus F, Murakami T, et al. State-dependent and timing-dependent bidirectional associative plasticity in the human SMA-M1 network. J. Neurosci. Oct 2011;31(43):15376-15383.

25. Green PE, Ridding MC, Hill KD, Semmler JG, Drummond PD, Vallence AM. Supplementary motor area-primary motor cortex facilitation in younger but not older adults. Neurobiol. Aging. Apr 2018;64:85-91. 
medRxiv preprint doi: https://doi.org/10.1101/2022.02.22.22270921; this version posted February 24, 2022. The copyright holder for this preprint (which was not certified by peer review) is the author/funder, who has granted medRxiv a license to display the preprint in

SMA-M1 connectivity in Parkinson's disease

26. Rossini PM, Rossini L, Ferreri F. Brain-Behavior Relations Transcranial Magnetic Stimulation: A Review. IEEE Eng. Med. Biol. Mag. Jan-Feb 2010;29(1):84-95.

27. Hallett M. Transcranial magnetic stimulation: A primer. Neuron. Jul 2007;55(2):187-199.

28. Barker AT, Jalinous R. Non-invasive magnetic stimulation of human motor cortex. Lancet. 1985;1(8437):1106-1107.

29. Rurak BK, Rodrigues JP, Power BD, Drummond PD, Vallence AM. Reduced SMA-M1 connectivity in older than younger adults measured using dual-site TMS. Eur J Neurosci. Sep 12021.

30. Muakkassa KF, Strick PL. Frontal lobe inputs to primate motor cortex: Evidence for four somatotopically organized 'premotor' areas. Brain Research. 1979/11/09/ 1979;177(1):176182.

31. Shima K, Tanji J. Involvement of NMDA and Non-NMDA receptors in the neuronal responses of the primary motor cortex to input from the supplementary motor area and somatosensory cortex: Studies of task-performing monkeys. The Japanese Journal of Physiology. 1998;48(4):275-290.

32. Rurak BK, Rodrigues JP, Power BD, Drummond PD, Vallence AM. Test re-test reliability of dual-site TMS measures of SMA-M1 connectivity differs across inter-stimulus intervals in younger and older adults. Neuroscience. Jul 30 2021;472:11-24.

33. Lu MK, Chiou SM, Ziemann U, Huang HC, Yang YW, Tsai CH. Resetting tremor by single and paired transcranial magnetic stimulation in Parkinson's disease and Essential tremor. Clinical Neurophysiology. Dec 2015;126(12):2330-2336.

34. Zipp P. Recommendations for the standardization of lead positions in surface electromyography. European Journal of Applied Physiology and Occupational Physiology. 1982;50(1):41-54.

35. Jitkritsadakul O, Jagota $P$, Bhidayasiri R. Pathophysiology of parkinsonian tremor: A focused narrative review. Asian Biomed. 2016;10(1):15-22.

36. Groppa S, Oliviero A, Eisen A, et al. A practical guide to diagnostic transcranial magnetic stimulation: Report of an IFCN committee. Clinical Neurophysiology. May 2012;123(5):858882.

37. Pellegrini $\mathrm{M}$, Zoghi $\mathrm{M}$, Jaberzadeh $\mathrm{S}$. A checklist to reduce response variability in studies using transcranial magnetic stimulation for assessment of corticospinal excitability: A systematic review of the literature. Brain Connect. Mar 2020;10(2):53-71.

38. Goetz CG, Tilley BC, Shaftman SR, et al. Movement disorder society - sponsored revision of the unified Parkinson's disease rating scale (MDS-UPDRS): Scale presentation and clinimetric testing results. Mov. Disord. Nov 2008;23(15):2129-2170.

39. Nimon KF. Statistical assumptions of substantive analyses across the general linear model: A mini-review. Frontiers in psychology. 2012;3.

40. Arai N. Effective connectivity between human supplementary motor area and primary motor cortex: a paired-coil TMS study. Experimental brain research. 2012 2012;220(1):79-87.

41. Serbruyns L, Gooijers J, Caeyenberghs K, et al. Bimanual motor deficits in older adults predicted by diffusion tensor imaging metrics of corpus callosum subregions. Brain Struct. Funct. Jan 2015;220(1):273-290.

42. Sullivan EV, Rohlfing T, Pfefferbaum A. Quantitative fiber tracking of lateral and interhemispheric white matter systems in normal aging: Relations to timed performance. Neurobiol. Aging. Mar 2010;31(3):464-481.

43. Dirkx MF, den Ouden $\mathrm{H}$, Aarts $\mathrm{E}$, et al. The cerebral network of Parkinson's tremor: An effective connectivity fMRI study. J. Neurosci. May 2016;36(19):5362-5372.

44. Shindo K, Shima K, Tanji J. Spatial-distribution of thalamic projections to the supplementary motor area and the primary motor cortex - a retrograde multiple labeling study in the macaque monkey J. Comp. Neurol. Jun 1995;357(1):98-116. 
medRxiv preprint doi: https://doi.org/10.1101/2022.02.22.22270921; this version posted February 24, 2022. The copyright holder for this preprint (which was not certified by peer review) is the author/funder, who has granted medRxiv a license to display the preprint in

perpetuity.

SMA-M1 connectivity in Parkinson's disease

45. Albin RL, Young AB, Penney JB. The functional-anatomy of disorders of the basal ganglia. Trends in Neurosciences. Feb 1995;18(2):63-64.

46. Graybiel AM. Neurotransmitters and neuromodulators in the basal ganglia. Trends in Neurosciences. Jul 1990;13(7):244-254.

47. Helmich RC. Cerebral causes and consequences of parkinsonian resting tremor: a tale of two circuits? Brain (London, England : 1878). 2012 2012;135:3206-3226.

48. Helmich RC, Janssen MJR, Oyen WJG, Bloem BR, Toni I. Pallidal dysfunction drives a cerebellothalamic circuit into Parkinson tremor. Ann. Neurol. Feb 2011;69(2):269-281.

49. Wiesendanger $\mathrm{R}$, Wiesendanger $M$. The thalamic connections with medial area- 6 (supplementary motor cortex) in the monkey (macaca-fascicularis). Experimental Brain Research. 1985;59(1):91-104.

50. Luo C, Song W, Chen $Q$, Yang J, Gong $Q$, Shang H-F. White matter microstructure damage in tremor-dominant Parkinson's disease patients. Neuroradiology. 2017;59(7):691-698.

51. Wu T, Hallett M. The cerebellum in Parkinson's disease. Brain. 2013 2013;136:696-709.

52. Yu H, Sternad D, Corcos DM, Vaillancourt DE. Role of hyperactive cerebellum and motor cortex in Parkinson's disease. Neuroimage. Mar 2007;35(1):222-233.

53. Carrillo F, Palomar FJ, Conde V, et al. Study of cerebello-thalamocortical pathway by transcranial magnetic stimulation in Parkinson's disease. Brain stimulation. 2013 2013;6(4):582-589.

54. Ni Z, Pinto $A D$, Lang $A E$, Chen R. Involvement of the cerebellothalamocortical pathway in Parkinson disease. Ann. Neurol. Dec 2010;68(6):816-824.

55. Schirinzi T, Di Lorenzo F, Ponzo V, et al. Mild cerebello-thalamo-cortical impairment in patients with normal dopaminergic scans (SWEDD). Parkinsonism Relat. Disord. 7// 2016;28:23-28.

56. Rurak BK, Rodrigues JP, Power BD, Drummond PD, Vallence AM. Reduced cerebellar brain inhibition measured using dual-site TMS in older than in younger adults. The Cerebellum. 2021.

57. Shirota $Y$, Hamada M, Terao $Y$, et al. Increased primary motor cortical excitability by a singlepulse transcranial magnetic stimulation over the supplementary motor area. Experimental Brain Research. Jun 2012;219(3):339-349.

58. Di Lazzaro V, Pilato F, Dileone $M$, et al. GABA receptor subtype specific enhancement of inhibition in human motor cortex GABA receptor subtype-specific enhancement of SICI. The Journal of Physiology. 2006 2006;575(3):721-726.

59. Ziemann U, Lonnecker S, Steinhoff BJ, Paulus W. The effect of lorazepam on the motor cortical excitability in man. Experimental Brain Research. Apr 1996;109(1):127-135.

60. Ziemann U, Tergau F, Wischer S, Hildebrandt J, Paulus W. Pharmacological control of facilitatory I-wave interaction in the human motor cortex. A paired transcranial magnetic stimulation study. Electroencephalography and Clinical Neurophysiology/Electromyography and Motor Control. 8// 1998;109(4):321-330.

61. Shirota Y, Ohminami S, Tsutsumi R, et al. Increased facilitation of the primary motor cortex in de novo Parkinson's disease. Parkinsonism Relat. Disord. 2019/09/01/ 2019;66:125-129.

62. Ni Z, Bahl N, Gunraj CA, Mazzella F, Chen R. Increased motor cortical facilitation and decreased inhibition in Parkinson disease. Neurology. May 2013;80(19):1746-1753.

63. Guerra A, Suppa A, D'Onofrio V, et al. Abnormal cortical facilitation and L-dopa-induced dyskinesia in Parkinson's disease. Brain Stimulation. 2019/11/01/ 2019;12(6):1517-1525.

64. Berardelli A, Abbruzzese $G$, Chen $R$, et al. Consensus paper on short-interval intracortical inhibition and other transcranial magnetic stimulation intracortical paradigms in movement disorders. Brain Stimulation. 7// 2008;1(3):183-191.

65. Ridding MC, Inzelberg R, Rothwell JC. Changes in excitability of motor cortical circuitry in patients with Parkinson's disease. Ann. Neurol. 1995 1995;37(2):181-188. 
medRxiv preprint doi: https://doi.org/10.1101/2022.02.22.22270921; this version posted February 24, 2022. The copyright holder for this preprint (which was not certified by peer review) is the author/funder, who has granted medRxiv a license to display the preprint in

perpetuity.

SMA-M1 connectivity in Parkinson's disease

66. MacKinnon CD, Gilley EA, Weis-McNulty A, Simuni T. Pathways mediating abnormal intracortical inhibition in Parkinson's disease. Ann. Neurol. 2005 2005;58(4):516-524.

67. Ammann C, Dileone M, Pagge C, et al. Cortical disinhibition in Parkinson's disease. Brain. 2020;143(11):3408-3421.

68. Thenganatt MA, Jankovic J. Parkinson disease subtypes. JAMA Neurol. 2014;71(4):499-504.

69. Doder M, Rabiner EA, Turjanski N, Lees AJ, Brooks DJ. Tremor in Parkinson's disease and serotonergic dysfunction - An C-11-WAY 100635 PET study. Neurology. Feb 2003;60(4):601605.

70. Qamhawi Z, Towey D, Shah B, et al. Clinical correlates of raphe serotonergic dysfunction in early Parkinson's disease. Brain. Oct 2015;138:2964-2973.

71. Delaville $C$, Deurwaerdère PD, Benazzouz A. Noradrenaline and Parkinson's disease. Frontiers in Systems Neuroscience. 2011;5:31-31.

72. Mercuri NB, Bernardi G. The 'magic' of I-dopa: Why is it the gold standard Parkinson's disease therapy? Trends in Pharmacological Sciences. 2005/07/01/ 2005;26(7):341-344.

73. Riekkinen $\mathrm{M}$, Kejonen $\mathrm{K}$, Jakala $\mathrm{P}$, Soininen $\mathrm{H}$, Riekkinen P. Reduction of noradrenaline impairs attention and dopamine depletion slows responses in Parkinson's disease. Eur. J. Neurosci. Apr 1998;10(4):1429-1435.

74. Politis $M$, Loane $C$. Serotonergic dysfunction in Parkinson's disease and its relevance to disability. Scientific World Journal. 2011/10/17 2011;11:172893.

75. Tork I. Anatomy of the serotonergic system. Ann.NY Acad.Sci. Oct 1990;600:9-33.

76. Bara-Jimenez W, Bibbiani F, Morris MJ, et al. Effects of serotonin $5-H T 1 A$ agonist in advanced Parkinson's disease. Mov. Disord. 2005;20(8):932-936.

77. Di Matteo V, Pierucci M, Esposito E, Crescimanno G, Benigno A, Di Giovanni G. Serotonin modulation of the basal ganglia circuitry: Therapeutic implication for Parkinson's disease and other motor disorders. Progress in Brain Research. Vol 172: Elsevier; 2008:423-463.

78. Politis M, Niccolini F. Serotonin in Parkinson's disease. Behavioural Brain Research. 2015/01/15/ 2015;277:136-145.

79. Loane C, Wu K, Bain P, Brooks DJ, Piccini P, Politis M. Serotonergic loss in motor circuitries correlates with severity of action-postural tremor in PD. Neurology. 2013;80(20):1850-1855.

80. Bludau S, Bzdok D, Gruber $O$, et al. Medial prefrontal aberrations in major depressive disorder revealed by cytoarchitectonically informed voxel-based morphometry. Am J Psychiatry. 2016;173(3):291-298.

81. Rascol $O$, Sabatini $U$, Chollet $F$, et al. Supplementary and primary sensory motor area activity in Parkinson's disease: Regional cerebral blood flow changes during finger movements and effects of apomorphine. Arch. Neurol. 1992;49(2):144-148.

82. Jenkins $I H$, Fernandez $W$, Playford ED, et al. Impaired activation of the supplementary motor area in Parkinson's-disease is reversed when akinesia is treated with apomorphine. Ann. Neurol. Dec 1992;32(6):749-757.

83. Zhang JQ, Wei LQ, Hu XF, et al. Akinetic-rigid and tremor-dominant Parkinson's disease patients show different patterns of intrinsic brain activity. Parkinsonism Relat. Disord. Jan 2015;21(1):23-30.

84. van Nuland AJM, den Ouden HEM, Zach H, et al. GABAergic changes in the thalamocortical circuit in Parkinson's disease. Hum. Brain Mapp. Mar 2020;41(4):1017-1029.

85. Dirkx MF, Zach H, van Nuland A, Bloem BR, Toni I, Helmich RC. Cerebral differences between dopamine-resistant and dopamine-responsive Parkinson's tremor. Brain. Oct 2019;142:3144-3157.

86. Zach H, Dirkx MF, Pasman JW, Bloem BR, Helmich RC. Cognitive stress reduces the effect of levodopa on Parkinson's resting tremor. CNS Neurosci. Ther. Mar 2017;23(3):209-215.

87. Zach H, Dirkx M, Bloem BR, Helmich RC. The Clinical evaluation of Parkinson's tremor. J. Parkinsons Dis. 2015;5(3):471-474. 
medRxiv preprint doi: https://doi.org/10.1101/2022.02.22.22270921; this version posted February 24, 2022. The copyright holder for this preprint (which was not certified by peer review) is the author/funder, who has granted medRxiv a license to display the preprint in It is made available under a CC-BY-ND 4.0 International license .

SMA-M1 connectivity in Parkinson's disease

88. Michely J, Volz L, Barbe MT, et al. Dopaminergic modulation of motor network dynamics in Parkinson's disease. Brain. Mar 2015;138:664-678.

89. Tahmasian M, Bettray LM, van Eimeren $T$, et al. A systematic review on the applications of resting-state $\mathrm{fMRI}$ in Parkinson's disease: Does dopamine replacement therapy play a role? Cortex. 2015/12/01/ 2015;73:80-105.

90. Zhuang XX, Mazzoni P, Kang UJ. The role of neuroplasticity in dopaminergic therapy for Parkinson disease. Nat. Rev. Neurol. May 2013;9(5):248-256.

91. Pahwa R. Levodopa-related wearing-off in Parkinson's disease: identification and management. Current medical research and opinion. 2009 2009;25(4):841-849.

92. Ziemann U, Paulus W, Nitsche MA, et al. Consensus: Motor cortex plasticity protocols. Brain Stimulation. 7// 2008;1(3):164-182.

93. Buch ER, Johnen VM, Nelissen N, O'Shea J, Rushworth MFS. Noninvasive associative plasticity induction in a corticocortical pathway of the human brain. J. Neurosci. Nov 2011;31(48):17669-17679.

94. Lu MK, Tsai CH, Ziemann U. Cerebellum to motor cortex paired associative stimulation induces bidirectional STDP-like plasticity in human motor cortex. Front. Hum. Neurosci. 2012;6:260.

95. Veniero DD, Ponzo V, Koch G. Paired associative stimulation enforces the communication between interconnected areas. J. Neurosci. 2013 2013;33(34):13773-13783.

96. Chiappini E, Borgomaneri S, Marangon M, Turrini S, Romei V. Driving associative plasticity in premotor-motor connections through a novel paired associative stimulation based on longlatency cortico-cortical interactions. Brain Stimul. 2020:1461-1463. 
(A) $\mathrm{SI}_{1 \mathrm{mv} \text {-alone coil placement }}$

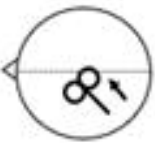

\section{M1 stimulation site:}

optimal M1 site to elicit $\sim 1 \mathrm{mV}$ MEP amplitude in the resting

$\mathrm{FDI}$
(B) Dual-site coil placement

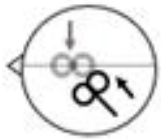

SMA stimulation site:

$4 \mathrm{~cm}$ anterior to $\mathrm{Cz}$
(C) $\mathrm{SI}_{1 \mathrm{mv}}$-alone trial

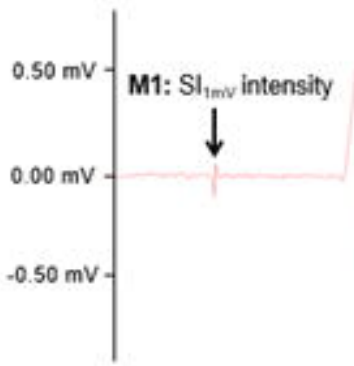

MEP amplitude
(D) Dual-site trial

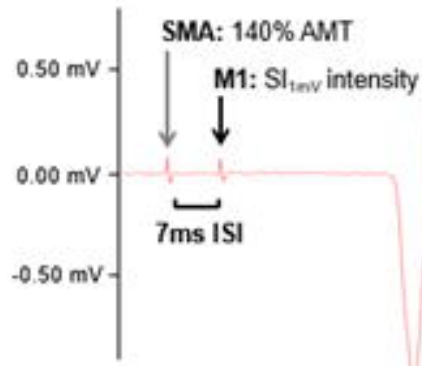

MEP amplitude

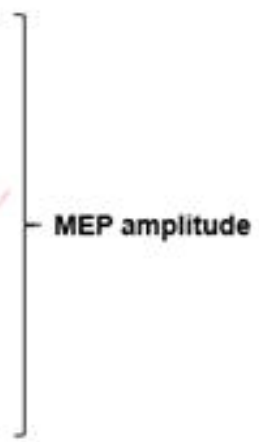

SMA-M1 connectivity: the mean dual-site MEP amplitude as a ratio of the mean S1 1 mv-alone MEP amplitude.

(E) Experimental procedure for session 1 and session 2

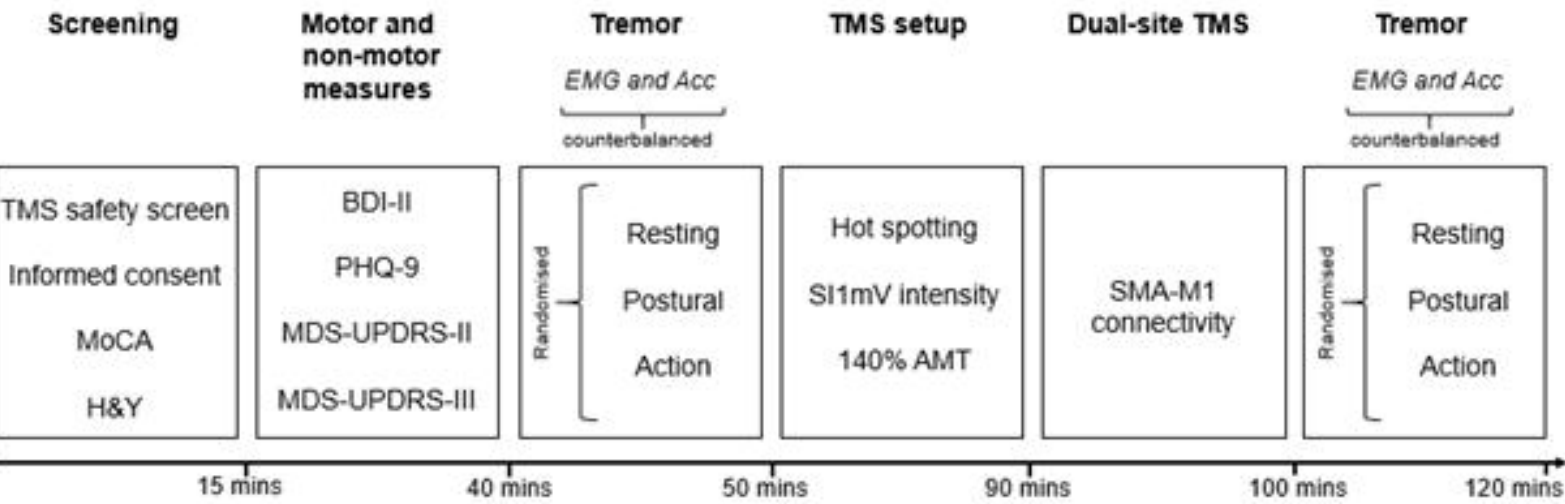

M1, primary motor cortex, MEP, motor evoked potential; FDI, first dorsal interosseous; SMA, supplementary motor area; SI1mV, stimulation intensity; SI1mV-alone, stimulation intensity that elicited $\sim 1 \mathrm{mV}$ peak-to-peak MEPS; ISI, inter-stimulus interval; MoCA, Montreal Cognitive Assessment; H\&Y, Hoehn \& Yahr Scale; BDI, Beck Depression Index, PHQ, Patient Health Questionnaire; MDS-UPDRS, Movement Disorder Society-Unified PD Rating Scale; EMG, electromyography; Acc, accelerometer 


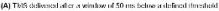

Trensor kust

7remer burg:

Tws puias

asouv

uwow

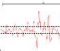

Nex ne-
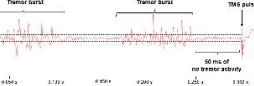

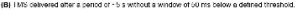

ENG attorv

TMS pusa

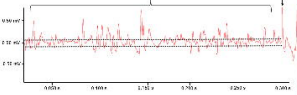




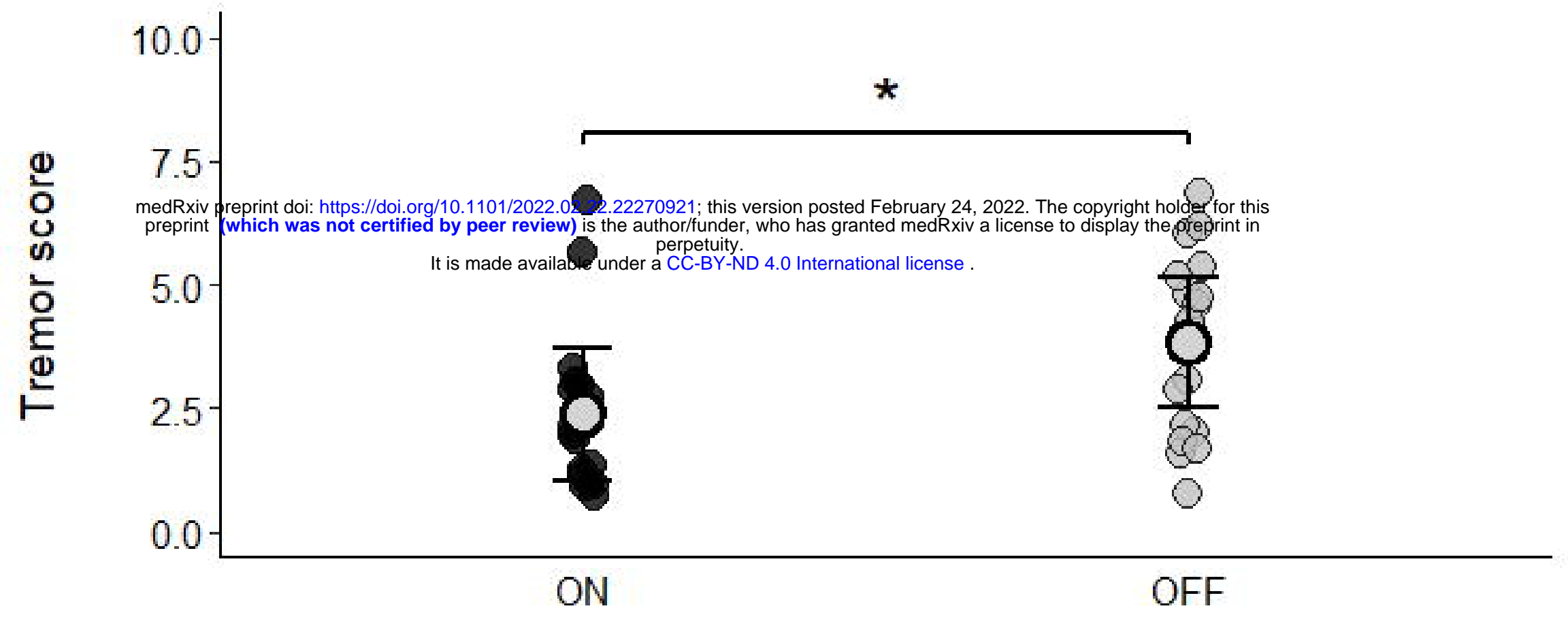

\section{(B) EMG}

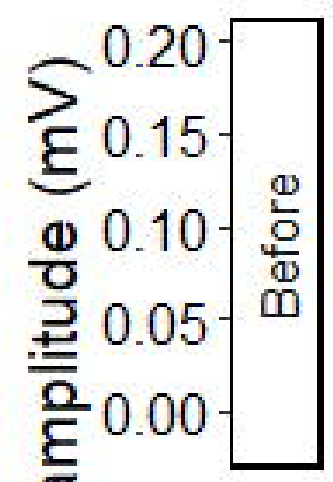

$\bigcirc$
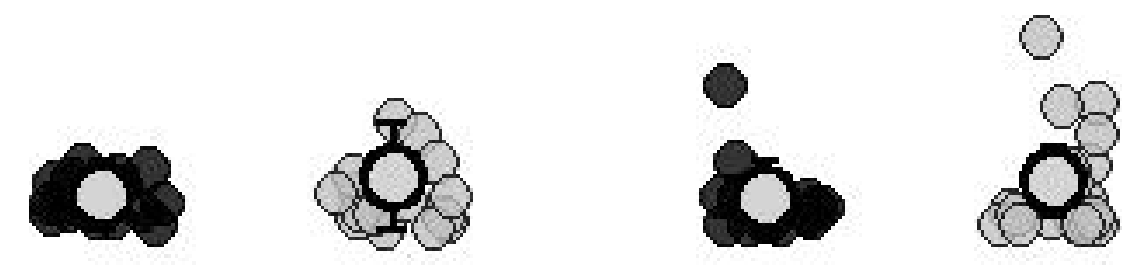

ธั

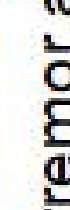
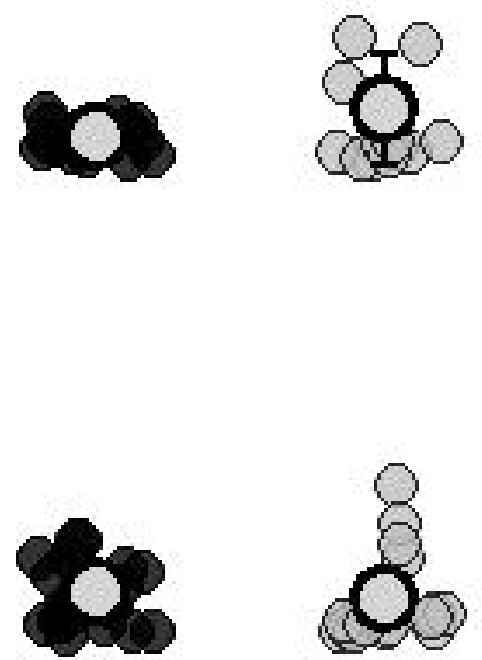

0

变

(1)
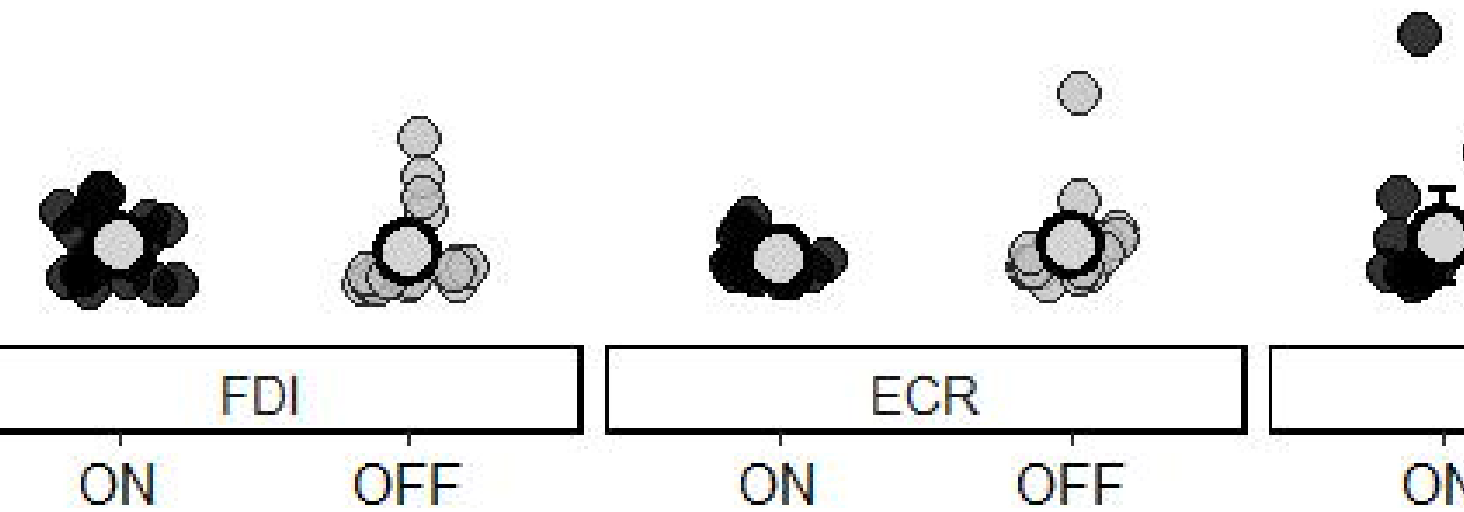

o

E

(C) Accelerometer

过
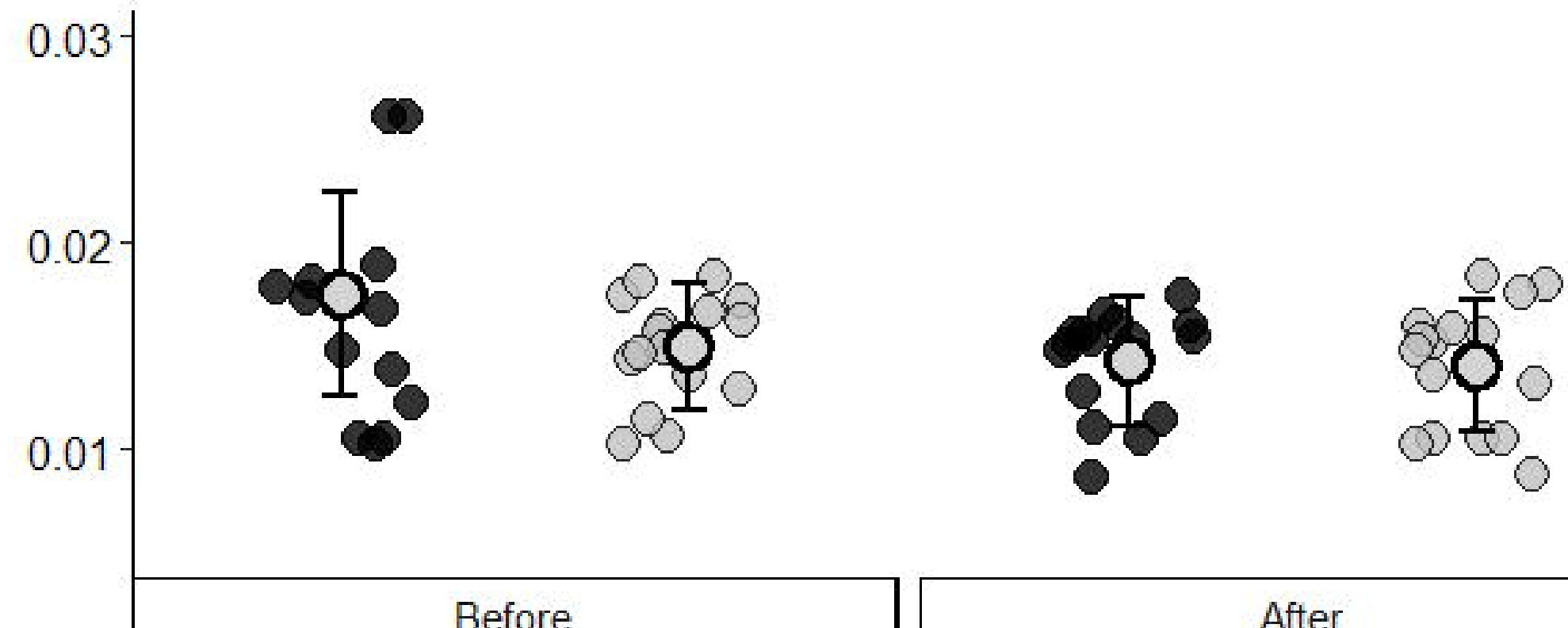


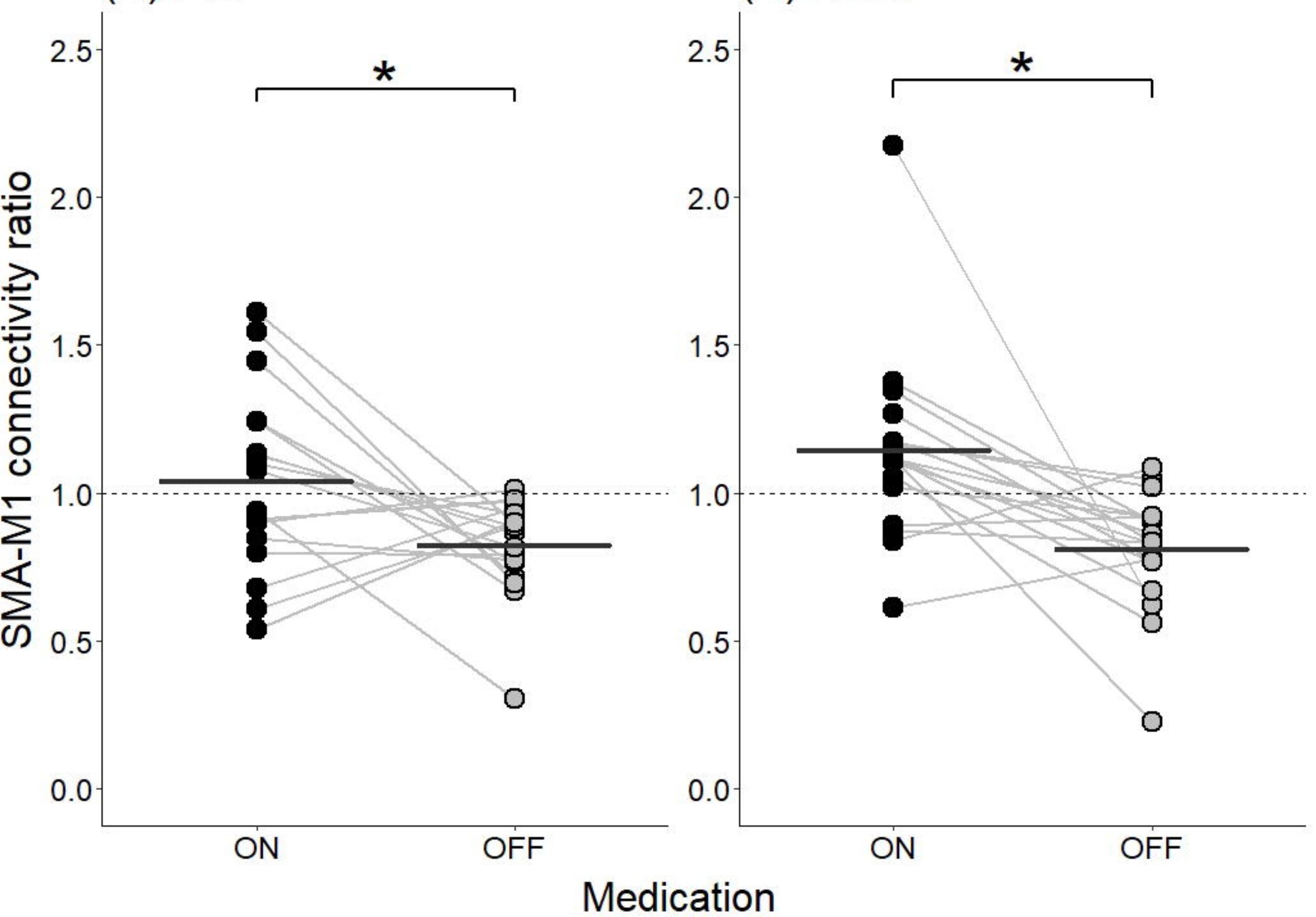


(A) ON medication, before TMS

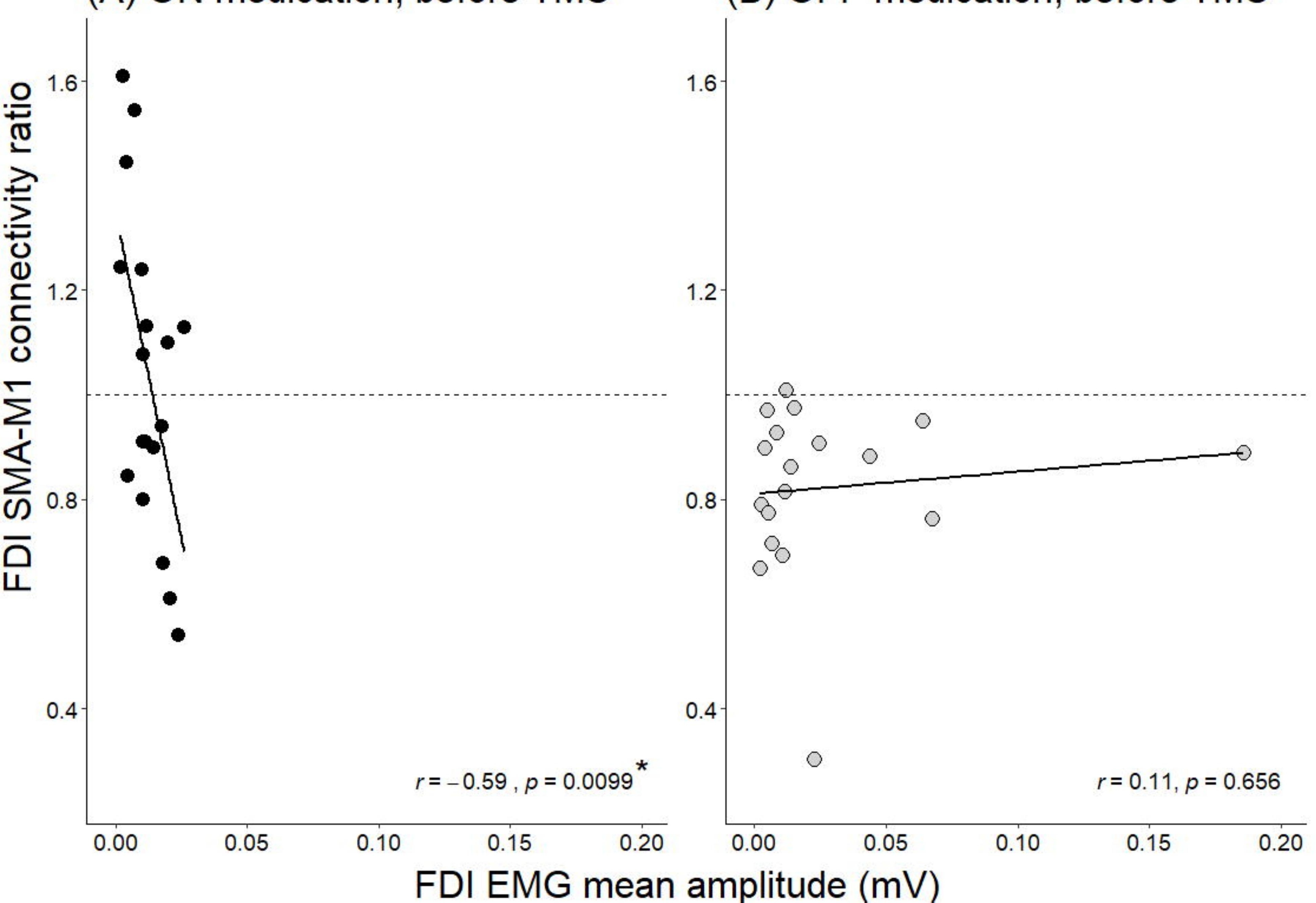


Resting tremor measured using acceleration medRxiv preprint doi: https://doi.org/10.1101/2022.02.22.22270921; this version posted February 24, 2022. The copyright holder for this
preprint (which was not certified by peer review) is the author funder, who has granted medRxiv a license to display the preprint in

It is made available under a CC-BY-ND 4.0 International license .
(A) ON medication, before TMS
(B) OFF medication, before TMS

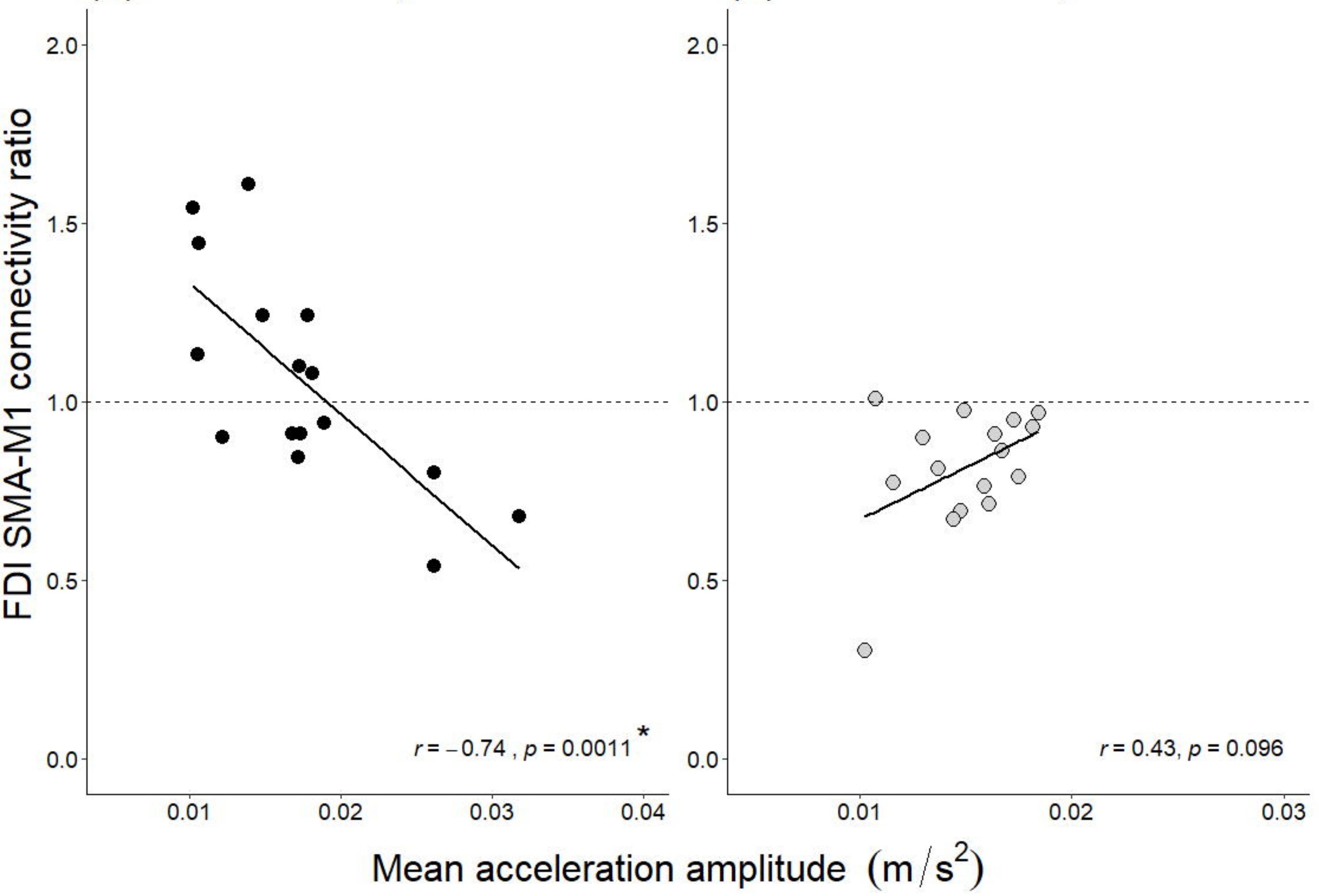

